\title{
Cytokine and Chemokine Signals of $T$-Cell Exclusion in Tumors
}

\author{
Yu Zhang ${ }^{1,2}$, Xin-yuan Guan ${ }^{2 *}$ and Peng Jiang ${ }^{1 *}$ \\ 1 Cancer Data Science Lab, Center for Cancer Research, National Cancer Institute, National Institutes of Health, Bethesda, \\ MD, United States, ${ }^{2}$ Department of Clinical Oncology, University of Hong Kong, Hong Kong, Hong Kong
}

OPEN ACCESS

Edited by:

Jason J. Luke,

University of Pittsburgh Medical

Center, United States

Reviewed by:

Gregory B. Lesinski,

Emory University, United States

Lubor Borsig,

University of Zurich, Switzerland

*Correspondence:

Xin-yuan Guan

xyguan@hku.hk

Peng Jiang

peng.jiang@nih.gov

Specialty section:

This article was submitted to

Cancer Immunity and

Immunotherapy,

a section of the journal

Frontiers in Immunology

Received: 13 August 2020

Accepted: 30 October 2020

Published: 14 December 2020

Citation:

Zhang Y, Guan X-y and Jiang P (2020)

Cytokine and Chemokine Signals of

$T$-Cell Exclusion in Tumors.

Front. Immunol. 11:594609.

doi: 10.3389/fimmu.2020.594609
The success of cancer immunotherapy in solid tumors depends on a sufficient distribution of effector T cells into malignant lesions. However, immune-cold tumors utilize many T-cell exclusion mechanisms to resist immunotherapy. T cells have to go through three steps to fight against tumors: trafficking to the tumor core, surviving and expanding, and maintaining the memory phenotype for long-lasting responses. Cytokines and chemokines play critical roles in modulating the recruitment of $T$ cells and the overall cellular compositions of the tumor microenvironment. Manipulating the cytokine or chemokine environment has brought success in preclinical models and early-stage clinical trials. However, depending on the immune context, the same cytokine or chemokine signals may exhibit either antitumor or protumor activities and induce unwanted side effects. Therefore, a comprehensive understanding of the cytokine and chemokine signals is the premise of overcoming T-cell exclusion for effective and innovative anti-cancer therapies.

Keywords: T-cell exclusion, cell therapy, immunotherapy, cytokine, chemokine

\section{INTRODUCTION}

Cancer immunotherapy aims to treat malignancies by leveraging the human immune system's potential, especially cytotoxic T cells that target tumor-specific antigens. However, T-cell exclusion in tumors presents a significant factor for the adverse outcome of cancer patients and the resistance to cancer immunotherapies $(1,2)$. CD8 T cells and subgroups of CD4 helper T cells are primary contributors to antitumor immunity (3). Activated $\mathrm{T}$ cells need to penetrate the tumor core for their cytotoxic activity. Meanwhile, the infiltrating T cells need to survive, proliferate, and keep active in the hostile tumor microenvironment (TME). Cold tumors, characterized by a lack of effector T cells, can exclude $\mathrm{T}$ cells through many mechanisms, such as lack of tumor antigens, defect in antigen presentation, absence of T-cell activation, and the deficit of trafficking signals toward the tumor core (4). 
Cytokines are small soluble proteins released by the malignant, stromal, and immune cells in the TME. Upon binding to their cognate receptors and triggering the intracellular pathway, cytokines can regulate the growth, apoptosis, activation, and differentiation of target cells (5). Chemokines, a subcategory of cytokines, provide the chemotactic signals for immune cell trafficking to specific destinations (6). Studies have reported significant correlations between the concentration of cytokines and chemokines with the prognosis of cancer patients (7-9).

This review will discuss different cytokines and chemokines that influence effector T-cell exclusion, focusing on T-cell trafficking, survival, and differentiation. We will also summarize cytokinerelated therapies to promote $\mathrm{T}$-cell infiltration and enhance antitumor responses. Elucidating the signaling mechanisms in $\mathrm{T}$-cell exclusion and cytokine-mediated strategies to enhance the abundance of effector T cells at tumor sites is of great importance to the development of cancer immunotherapies.

\section{T-CELL TRAFFICKING: T CELLS NEED TO PENETRATE THE BATTLEFIELD}

A crucial factor for T-cell antitumor activity is the capabilities of specific and efficient trafficking. Upon primed and activated by antigen-presenting cells such as macrophages and dendritic cells (DC) in tumor-draining lymph nodes, $\mathrm{T}$ cells will migrate to tumor sites, exerting antigen-specific cytolytic functions. T-cell trafficking is a dynamic process involving rolling, tethering on the vascular endothelium (10), adhesion, extravasation, and chemotaxis (11) (Figure 1A).

\section{Signals for T Cells Crossing the Tumor Vasculature}

The activated $\mathrm{T}$ cells will first gain the expression of homing molecules, including ligands for E- and P-selectin, which enable the rolling of $\mathrm{T}$ cells on the tumor vessel endothelium (12). Activated $\mathrm{T}$ cells also gain the expression of leukocyte adhesion protein LFA-1 (ITGAL) and VLA-4 (ITGA4), which bind to the intercellular adhesion molecule 1 (ICAM1) and vascular cell adhesion molecule 1 (VCAM1) on endothelial cells (11). Then, the $\mathrm{T}$ cells may transmigrate through the tumor vessel in response to various environmental stimuli. Cytokines such as IL6 and TNFa can enhance the endothelium adhesion activity by promoting adhesion molecules' expression on tumor vessels $(13,14)$ (Table 1). One study demonstrated that IL6 signaling activated by systemic thermal therapy in a mouse model with the ovalbuminexpressing B16 tumor significantly upregulated E/P-selectin and ICAM1, which enhanced the CD8+ T-cell trafficking (13).

Besides the positive signals discussed above, there are negative signals that block effector T-cell adherence to the tumor endothelium and prevent the $\mathrm{T}$ cell recruitment to tumor sites (Table 2). The phenomenon is termed as endothelial cell anergy. For example, the angiogenic factors vascular endothelial growth factor (VEGF) and fibroblast growth factor 2 (FGF2) can cause endothelial cell anergy by repressing the expression of adhesion molecules ICAM1 and VCAM1 on the endothelium (76).
Meanwhile, high levels of growth factors, such as VEGF, PDGFC (74), and PGF (75), can induce immature tumor angiogenesis. The aberrant vascular permeability and irregular blood flow that come with tumor vessels will cause inefficient effector T cells extravasation.

These observations have suggested therapeutic approaches by targeting proangiogenic molecules. Anti-VEGF therapy produced synergistic antitumor responses with immune checkpoint blockade in phase I clinical trials of many cancer types (77). Also, anti-VEGF therapy resulted in significant clinical efficacy when combined with Chimeric Antigen Receptor (CAR)-T therapies by increasing tumor infiltration in humans (78). However, it is essential to note that the administration dose of anti-VEGF must be carefully considered. A low concentration of therapy could efficiently normalize tumor vasculature and enhance T-cell perfusion (79). However, a high dose of VEGF inhibitor will induce tumor-promoting hypoxic microenvironment by blocking the formation of tumor capillaries and causing insufficient oxygen supply $(78,80)$.

Notably, positive signals of T-cell extravasation may act as negative signals for $\mathrm{T}$-cell recruitment in a context-specific manner. For example, tumor necrosis factor (TNF), which enhances T-cell adhesion molecules, may impair the effector $\mathrm{T}$-cell infiltration by negatively regulating the formation of high endothelial venules (HEV) (81). HEVs are uniquely organized vessels in proximity to tumor sites and tightly associated with tertiary lymphoid structures (TLS). Tumors with HEV and TLS have a high density of effector $\mathrm{T}$ cells infiltration and favorable clinicaloutcome $(82,83)$.

\section{Chemotaxis for T Cells Trafficking to Tumor Core}

After extravasation, $\mathrm{T}$ cells need guidance from environmental stimuli to arrive at tumor sites. This process is chemotaxis. The expression of chemokine CXCligand (CXCL) 9, 10, and 11, secreted by tumor and stromal cells, are highly correlated to T-cell abundance in tumors of melanoma (84), lung $(84,85)$, and colorectal cancer (86). Moreover, high expression of CXCR3 ligands is significantly related to prolonged overall survival rate in cancer patients (87). Exploiting the therapeutic potential of CXCR3 ligands for antitumor T-cell recruitment has been successful in multiple preclinical models (23-26).

Notably, these CXCR3 ligands are all induced by interferon- $\gamma$, the effector cytokine secreted by cytotoxic $\mathrm{T}$ cells. However, intratumoral interferon $\gamma$ injection, which indeed increased the concentration of CXCL10 and CXCL11 in tumors, failed to induce the recruitment of effector $\mathrm{T}$ cells to human melanoma metastases in a clinical trial (88). Interferon- $\gamma$ may upregulate the expression of PD-L1 and IDO1, leading to T-cell exclusion (89). A high level of Interferon- $\gamma$ might compromise the combined anti-CTLA-4 and anti-PD-1 therapy in tumors with low tumor burden because Interferon- $\gamma$ induced the apoptosis of activated antigen-specific T cells (90).

Besides CXCR3 ligands, other chemokines, such as CCL5, CXCL16, CCL21, and CCL27, may positively correlate with effector T-cell density within tumors $(27,37,91)$. Recent studies showed that CCL5 may selectively mediate CD4 not CD8 effector T 


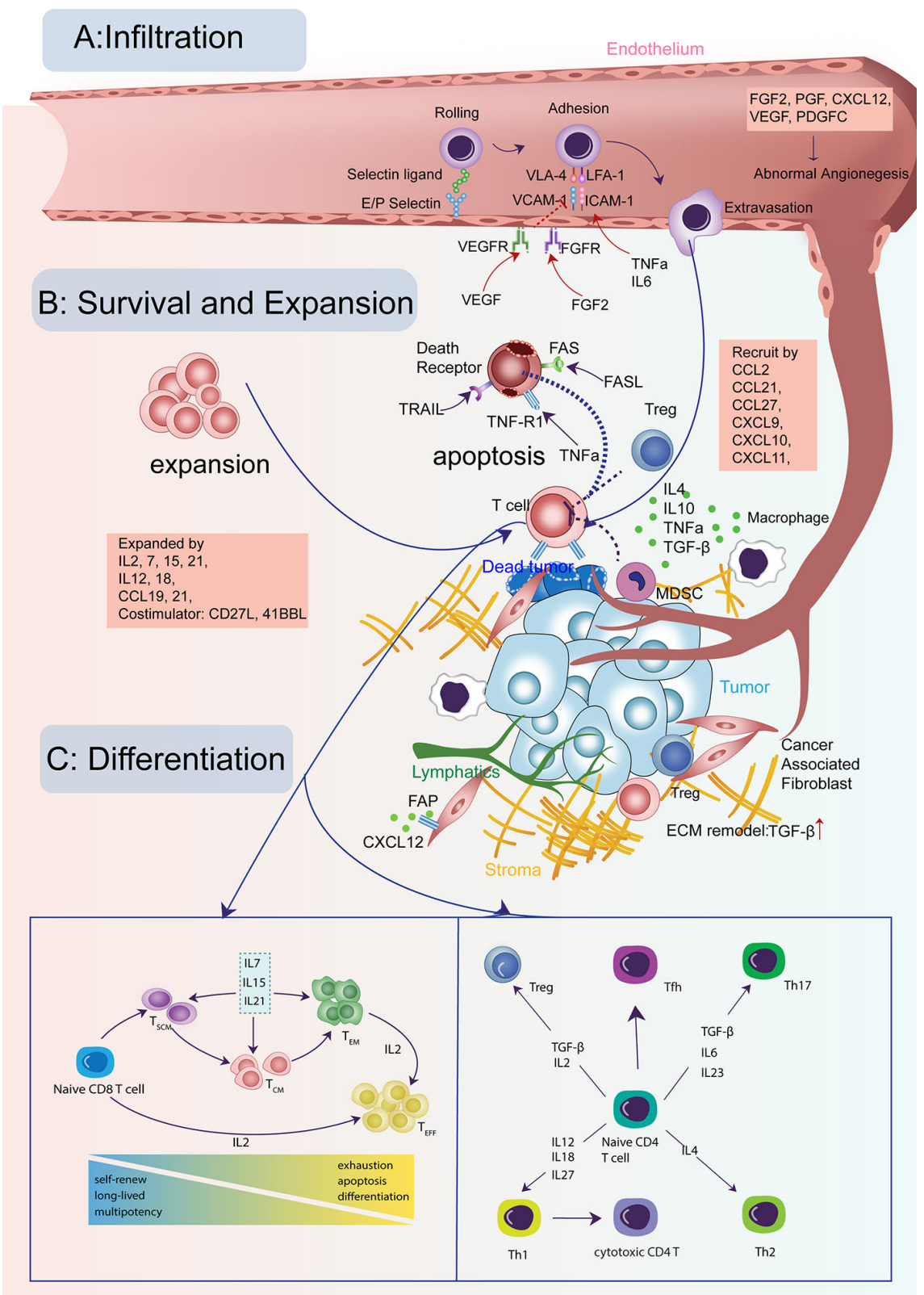

FIGURE 1 | Cytokine signals in the life-span of T cells in tumors. (A) T cells need to infiltrate into the tumor for their cytotoxic activity. This process is guided through a set of cytokine, chemokine, and growth factor signals for $T$ cells crossing the tumor vasculature and trafficking to tumor cores. (B) The infiltrating $T$ cells need to survive and expand for sufficient numbers with the help from many cytokines and avoid the apoptosis induced by other signals. (C) Both CD8 and CD4 T cells need to keep active with the right differentiation path for its long-lasting tumor-fighting capability, modulated by many cytokines and growth factors.

cells infiltration and enhance the therapeutic efficacy of checkpoint blockade in a mouse model of pancreatic cancer (92). However, the role of CCL5 on T-cell recruitment seems to be context-dependent. Another study showed that CCL5 upregulation is positively correlated with CD8 lymphocytes recruitment in the lung adenocarcinoma model (93). CCL27 is expressed in epidermal keratinocytes and mediates CCR10+T-cell homing to cutaneous tumors (40). One study employed an adenoviral vector to deliver chemokine CCL27 into tumors in a mouse model of B16BL6 melanoma and observed considerably increased recruitment of $\mathrm{T}$ cells (41) (Figure 2A).

\section{Negative Signals of T-Cell Trafficking Into Tumors}

Although several chemokines are positive signals of T-cell infiltration as summarized above, the tumor microenvironment is 
TABLE 1 | Positive signals of T-cell infiltration.

\begin{tabular}{|c|c|c|c|}
\hline Signal/Receptor & Producer/Target & Mechanisms & Therapy \\
\hline $\begin{array}{l}\text { IFNG/IFNGR1 } \\
+ \text { IFNGR2 }\end{array}$ & $\begin{array}{l}\text { Cytotoxic T cells/endothelial } \\
\text { cell, fibroblasts, tumor cell, } \\
\text { monocyte }\end{array}$ & $\begin{array}{l}\text { Interferon- } \gamma \text { induces CXCR3 ligands (CXCL9,10,11), thus } \\
\text { enhancing the CXCR3-mediated T-cell recruitment (15). }\end{array}$ & $\begin{array}{l}\text { Intravesical instillation of recombinant interferon- } \gamma \\
\text { inhibits the recurrence of bladder tumors in } \\
\text { patients (16). }\end{array}$ \\
\hline $\begin{array}{l}\text { (fn. 1) IL6/IL6R } \\
+ \text { +IL6ST }\end{array}$ & $\begin{array}{l}\text { T cell, macrophage, } \\
\text { endothelial cell, epithelial cell/ } \\
\text { endothelial cell }\end{array}$ & $\begin{array}{l}\text { IL6 trans-signaling enhances both E- and P-selectin } \\
\text { interactions and ICAM1 dependent T-cell transmigration on } \\
\text { tumor vessels (17). }\end{array}$ & $\begin{array}{l}\text { IL6-rich tumor microenvironment provided by } \\
\text { systemic thermal therapy improves cytotoxic T } \\
\text { cells' delivery to tumor lesions in mouse tumors } \\
\text { and patient tumor explants (13). }\end{array}$ \\
\hline $\begin{array}{l}\text { IL12A+IL12B/ } \\
\text { IL12RB1 + } \\
\text { IL12RB2 }\end{array}$ & $\begin{array}{l}\text { Phagocytic macrophage, DC/ } \\
\text { MDSC }\end{array}$ & $\begin{array}{l}\text { IL12 may attenuate the impaired T-cell trafficking mediated by } \\
\text { MDSCs by decreasing the percentage of MDSCs in tumors } \\
\text { (18). }\end{array}$ & $\begin{array}{l}\text { Treatment of IL12 significantly altered the } \\
\text { phenotype and suppressive function of MDSC in } \\
\text { mice (18). }\end{array}$ \\
\hline (fn. 2) TNF/ITGAV & $\begin{array}{l}\text { Lymphoid, mast, endothelial, } \\
\text { fibroblast, tumor cell/ } \\
\text { endothelial cell (19). }\end{array}$ & $\begin{array}{l}\text { TNF stimulation induces ICAM1 and VCAM1 expression on } \\
\text { endothelial cells for T-cell extravasation (14). }\end{array}$ & $\begin{array}{l}\text { The systemic administration of TNF had severe } \\
\text { toxicity (20). The fusion of TNF and ITGAV ligand } \\
\text { had antitumor effects in mice (21) }\end{array}$ \\
\hline $\begin{array}{l}\text { CXCL9,10,11/ } \\
\text { CXCR3 }\end{array}$ & $\begin{array}{l}\text { Endothelial, fibroblast, tumor } \\
\text { cell, monocyte/CXCR3+ T } \\
\text { cell }\end{array}$ & $\begin{array}{l}\text { These chemokines are induced by interferon- } \gamma \text { and share a } \\
\text { receptor CXCR3, directing the migration of activated T and } \\
\text { NK cells (22). }\end{array}$ & $\begin{array}{l}\text { Virus-directed expression of CXCL10, 11, or } \\
\text { recombinant CXCL10 injection in tumors can } \\
\text { recruit anticancer T cells in mice (23-26). }\end{array}$ \\
\hline CXCL16/CXCR6 & $\begin{array}{l}\text { Tumor cell, macrophage, DC, } \\
\text { Fibroblast/activated T cell, } \\
\text { Th1, NK cell }\end{array}$ & $\begin{array}{l}\text { CXCL16 is chemotactic for cells expressing its receptor } \\
\text { CXCR6 }(27,28) \text {. }\end{array}$ & \\
\hline CCL2/CCR2 & Endothelial cells/Th1, CD8 T & $\begin{array}{l}\text { Actin fibers beneath the endothelial plasma membranes will } \\
\text { dock vesicles storing CCL2. The tight lymphocyte-endothelial } \\
\text { synapses will release the chemokine to promote the } \\
\text { transendothelial T-cell migration (29). }\end{array}$ & $\begin{array}{l}\text { CAR/CCR2 T cells displayed greater homing and } \\
\text { tumor-killing in malignant pleural mesothelioma } \\
\text { (30) and neuroblastoma tumors (31) in mice. }\end{array}$ \\
\hline $\begin{array}{l}\text { CCL3, } 4,5 \text { (fn. 3)/ } \\
\text { CCR5 }\end{array}$ & $\begin{array}{l}\text { Epithelial cell, fibroblast, } \\
\text { monocyte, NK cell, DC, } \\
\text { endothelial cell, macrophage, } \\
\text { lymphocyte/CCR5+ DC }\end{array}$ & $\begin{array}{l}\text { CCL3,4,5 can indirectly promote effector T-cell recruitment by } \\
\text { recruiting the DCs into tumor sites. Then, DC, in turn, recruits } \\
\text { cytotoxic T cells into the tumor by producing CXCR3 ligands } \\
\text { CXCL9 and CXCL10 }(32,33) \text {. }\end{array}$ & $\begin{array}{l}\text { Combining adenoviral delivery of CCL3 with the } \\
\text { adoptive transfer of activated effector T cells } \\
\text { significantly attracted activated T cells to the } \\
\text { murine melanoma tumors (34). }\end{array}$ \\
\hline CCL21/CCR7 & $\begin{array}{l}\text { Lymphatic vessels, } \\
\text { fibroblasts, HEV in lymph } \\
\text { nodes/CCR7+ T cell, DC ( } 35 \text {, } \\
\text { 36) }\end{array}$ & $\begin{array}{l}\text { CCL21 can significantly increase the CD4+ and CD8+ T cells, } \\
\text { and DCs infiltration to tumors }(37,38) \text {. }\end{array}$ & $\begin{array}{l}\text { Intratumoral injection of CCL21 induced DC and } \\
\text { T-cell infiltration, causing tumor reduction in a } \\
\text { murine lung cancer model (39). }\end{array}$ \\
\hline CCL27/CCR10 & $\begin{array}{l}\text { Keratinocytes/CCR } 10+\text { skin- } \\
\text { homing T cells }\end{array}$ & $\begin{array}{l}\text { Skin-associated chemokine CCL } 27 \text { is specifically expressed in } \\
\text { epidermal keratinocytes and mediates the recruitment of skin- } \\
\text { homing CCR } 10+\text { memory T cells to cutaneous sites (40). }\end{array}$ & $\begin{array}{l}\text { The tumor injection of adenoviral vector encoding } \\
\text { CCL27 attracted T cells and suppressed tumor } \\
\text { growth in a murine melanoma model (41). }\end{array}$ \\
\hline
\end{tabular}

a hostile environment containing many negative messages for effector T-cell chemotaxis. VEGF can inhibit NF- $\mathrm{KB}$ signaling induced endothelium activation, blocking the induction of chemokines CXCL10 and CXCL11, and impairing the T-cell infiltration (110). Another cytokine IL35, released by T regulatory cells (Treg), macrophages, or B cells (111), can limit antitumor Tcell recruitment and induce a significant decrease in the CD8: Treg ratio in a murine model.

Other factors reshaping the stromal structure will also contribute to reduced T-cell infiltration. Transforming growth factor-beta (TGF $\beta$ ) is a crucial regulator of epithelial-mesenchymal transition (EMT) in tumor cells. TGF $\beta$ plays a critical role in T-cell exclusion since the abundant tumor-stromal compartments induced by EMT will trap effector T cells from penetrating the tumor core (112). One study from a cohort of metastatic urothelial cancer patients receiving anti-PD-L1 therapy found that lack of response was related to activation of TGF $\beta$ signaling in fibroblasts (112). Moreover, TGF $\beta$ secreted by stromal cells will also promote angiogenic factors like VEGF and recruit immune suppressive cells such as Treg and myeloid-derived suppressor cell (MDSC) in tumors, further creating an unfavorable environment for T-cell trafficking.

TGF $\beta$ blockade has demonstrated safety and efficacy in different stages of preclinical models and clinical trials $(45,46,48)$. In a EMT6 mouse mammary carcinoma model that exhibited the $\mathrm{T}$ cellexclusion phenotype, combining anti-TGF $\beta$ antibody with antiPD-L1 therapy successfully blocked the TGF $\beta$ signaling in stromal cells, which facilitated $\mathrm{T}$ cells infiltration and tumor regression (112). Co-expression of a dominant-negative TGF $\beta$ receptor II of the CAR-T cells dramatically enhanced its potency of penetration, proliferation, cytokine secretion, and tumor-killing capability in prostate cancer mouse models (49). This therapy has entered Phase I clinical trial status. Additionally, M7824, a fusion compound targeting both TGF $\beta$ and PD-L1, is undergoing clinical testing as monotherapy and combination therapy with an adenovirus vaccine encoding the tumor-associated antigen TWIST1 $(49,113)$.

Many cytokines and chemokines have both well-defined functions and controversial roles in the literature, depending on their cellular context. For example, the tumor endothelium produces CCL2 stored in vesicles of actin fibers beneath the plasma membrane. The stored CCL2 may promote the transmigration capacity of T helper type 1 (Th1) and CD8 T cells after resting on the endothelium (29). However, the extracellular soluble CCL2, produced by variable cell types in tumors, may exert different functions in the antitumor immunity by recruiting macrophages, Tregs, and MDSCs (59-61). Although CCL2 has restricted clinical application, its receptor CCR2 could serve as a useful therapeutic target. CAR T cells engineered with 
TABLE 2 | Negative signals of T-cell infiltration.

\begin{tabular}{|c|c|c|c|}
\hline Signal/Receptor & Producer/Target & Mechanisms & Therapy \\
\hline $\begin{array}{l}\text { IL35 (IL12A+IL27B)/ } \\
\text { (fn. 4) IL12RB2+IL6ST }\end{array}$ & $\begin{array}{l}\text { Tregs, macrophages, B } \\
\text { cell/T cell }\end{array}$ & $\begin{array}{l}\text { Treg cells derived IL35 can decrease the intratumoral CD4+ } \\
\text { and CD8+ T cells infiltration. Also, the infiltrated T cells } \\
\text { displayed a less activated, effector memory phenotype (42). }\end{array}$ & $\begin{array}{l}\text { Neutralization of IL35 enhances antitumor } \\
\text { immunity in a genetically induced KP mouse } \\
\text { model (42). }\end{array}$ \\
\hline TGFB1/TGFBR1, 2, 3 & $\begin{array}{l}\text { Fibroblasts/Tumor epithelial } \\
\text { cell }\end{array}$ & $\begin{array}{l}\text { TGF } \beta \text { is a well-known regulator of EMT. Fibroblast induced } \\
\text { TGF } \beta \text { may reprogram peritumoral stromal fibroblasts and } \\
\text { exhibit a fibroblast- and collagen-rich tumor (43), which will } \\
\text { decrease the CD8+ T effector cell penetration in the tumor } \\
\text { (44). }\end{array}$ & $\begin{array}{l}\text { Inhibitors of TGF } \beta \text { and receptors have entered } \\
\text { clinical trials (45-48). CAR-T cells expressing a } \\
\text { dominant-negative TGF- } \beta \text { RII enhance T-cell } \\
\text { expansion and prostate cancer eradication in } \\
\text { clinical trials (49). }\end{array}$ \\
\hline CXCL1, 2, 5/CXCR2 & $\begin{array}{l}\text { Tumor cell, macrophage, } \\
\text { neutrophil/CXCR2+ MDSC }\end{array}$ & $\begin{array}{l}\text { CXCL1, 2, 5- CXCR2 signal promotes the recruitment of } \\
\text { MDSC to tumors (50). }\end{array}$ & $\begin{array}{l}\text { Several CXCR2 antagonists and inhibitors have } \\
\text { been tested in preclinical models and shown } \\
\text { anticancer effects }(51,52) \text {. }\end{array}$ \\
\hline (fn. 5) CXCL8/CXCR1, 2 & $\begin{array}{l}\text { Tumor cells, mast cells, } \\
\text { TAM, endothelial cells/ } \\
\text { CXCR1, 2+ Neutrophil, } \\
\text { MDSC }\end{array}$ & $\begin{array}{l}\text { CXCL8 (IL8) enhances the infiltration of immune- } \\
\text { suppressive cells expressing receptors (CXCR1, 2), such as } \\
\text { tumor-associated neutrophils and MDSCs (53). T cells do } \\
\text { not express CXCR1 and CXCR2 (54). }\end{array}$ & $\begin{array}{l}\text { CXCR1 or CXCR2 modified CARs markedly } \\
\text { enhance T-cell homing and persistence in murine } \\
\text { GBM tumors (54). }\end{array}$ \\
\hline CXCL12/CXCR4 & $\begin{array}{l}\text { FAP + CAF/CXCR4+ } \\
\text { MDSC, Endothelial cell, T } \\
\text { cell }\end{array}$ & $\begin{array}{l}\text { CXCL12 has chemo-repulsive effects on T cells (55). } \\
\text { CXCL12 promotes angiogenesis by recruiting endothelial } \\
\text { precursor cells (56). } \\
\text { CXCL12 also recruits MDSCs to tumors (57). }\end{array}$ & $\begin{array}{l}\text { AMD3100, a CXCR4 inhibitor, induced rapid } \\
\text { T-cell accumulation around cancer cells in mice } \\
\text { (58). }\end{array}$ \\
\hline CCL2/CCR2 & $\begin{array}{l}\text { Endothelial cell, tumor cell, } \\
\text { fibroblast, monocyte/CCR2 } \\
+ \text { TAM, MDSC, Treg }\end{array}$ & $\begin{array}{l}\text { Soluble CCL2 promotes the recruitments of TAM, MDSC, } \\
\text { and Treg to the tumor sites (59-61). }\end{array}$ & \\
\hline CCL5/CCR5 & $\begin{array}{l}\text { Epithelial cell, fibroblast, } \\
\text { monocyte, NK cell, DC, } \\
\text { endothelial cell, } \\
\text { macrophage, lymphocyte/ } \\
\text { CCR5+ TAM, Treg }\end{array}$ & $\begin{array}{l}\text { CCL5 regulates TAM and MDSC migration (62). It can also } \\
\text { recruit Treg to tumors (63). }\end{array}$ & \\
\hline CCL17/CCR4, 8 & $\begin{array}{l}\text { DC, Endothelial cell/CCR4 } \\
+, \text { CCR8+ cells. }\end{array}$ & $\begin{array}{l}\text { CCL17 induces chemotaxis in CCR4+ T cells, mainly Th2 } \\
\text { and Tregs, generating an immunosuppressive TME }(64,65) \text {. }\end{array}$ & $\begin{array}{l}\text { CAR- CD30 coexpressing CCR } 4 \text { T cells have an } \\
\text { improved homing and antitumor activity in the } \\
\text { murine Hodgkin tumor model (66). }\end{array}$ \\
\hline CCL22/CCR4 & TAMs/CCR4+ Treg, & $\begin{array}{l}\text { CCL22 enhances the recruitment of Tregs, thus decreasing } \\
\text { effector T-cell homing (67). }\end{array}$ & \\
\hline CCL28/CCR10 & $\begin{array}{l}\text { Tumor cells/CCR10+ skin- } \\
\text { homing T cells }\end{array}$ & $\begin{array}{l}\text { CCL28/CCR10 signals promote Treg recruitment in hypoxic } \\
\text { tumors (68). }\end{array}$ & \\
\hline VEGFNEGFR1, 2, NRP1 & $\begin{array}{l}\text { Tumor, Macrophage, } \\
\text { Endothelial, Fibroblast/ } \\
\text { Endothelial cell, Treg, } \\
\text { MDSC }\end{array}$ & $\begin{array}{l}\text { VEGF induces FASLG on endothelial cells, leading to T-cell } \\
\text { apoptosis during extravasation (69). VEGF recruits the } \\
\text { NRP1+ Tregs and VEGFR1,2+ MDSCs }(70,71) \text {. }\end{array}$ & $\begin{array}{l}\text { The anti-VEGFNEGFR is a standard therapy for } \\
\text { many tumor types (72). }\end{array}$ \\
\hline FGF2/FGFR1,2,3,4 & CAF/Endothelial cells & $\begin{array}{l}\text { FGF2 significantly blocks the adhesion molecules VCAM1 } \\
\text { and E-selectin expression (73). }\end{array}$ & \\
\hline PDGFC/PDGFRA & CAF/Endothelial cells & PDGFC acts as a proangiogenic signal (74). & \\
\hline PGF/FLT1 & TAMs/Endothelial cells & TAM production of PGF stimulates angiogenesis (75). & \\
\hline
\end{tabular}

CCR2 expression displayed satisfactory effector T-cell trafficking and antitumor efficacy in malignant pleural mesotheliomas (30) and neuroblastoma tumors (31) in mice.

Similarly to the application of CCR2, other cytokine-receptor pairs which contribute to immune-suppressive cells recruitment have shown therapeutic potentials in T-cell therapy. For example, CXCL8 recruits myeloid derived suppressor cells (MDSC) and neutrophils into tumors (53). CAR-T cells armed with CXCL8 receptors (CXCR1 and CXCR2) markedly enhanced $\mathrm{T}$ cells infiltration and led to complete antitumor responses in murine models ovarian cancer, pancreatic cancer, and glioblastoma (54). Another example is CCR4 receptor for CCL17 and CCL22, which recruit Treg and T helper type 2 (Th2) $(64,67)$. The CAR-CD30 T cells expressing CCR4 significantly enhanced the CAR T migration to tumor sites and achieved satisfactory tumor control in a Hodgkin tumor model (66).

\section{T-CELL SURVIVAL: T CELLS NEED TO SURVIVE ON THE BATTLEFIELD}

\section{Signals Supporting T-Cell Survival and Expansion}

Once T cells enter the tumor, the goal is to survive and proliferate in adequate numbers for efficient tumor killing (Figure 1B). Tumor infiltrating lymphocytes (TIL) manage to expand in the nutrientdeficient tumor microenvironment with the help of multiple cytokines (Table 3). Several studies have supported the pivotal role of the IL2 cytokine family (IL2, IL7, IL15, IL21) for CD8 T-cell expansion. IL2 was one of the earliest FDA-approved immunotherapies for metastatic melanoma and renal cell cancer $(94,117)$. Autologous TILs were transferred in conjunction with IL2 after ex vivo expansion with IL2, which mediated a durable and completed tumor regression in $22 \%$ of the heavily pretreated 


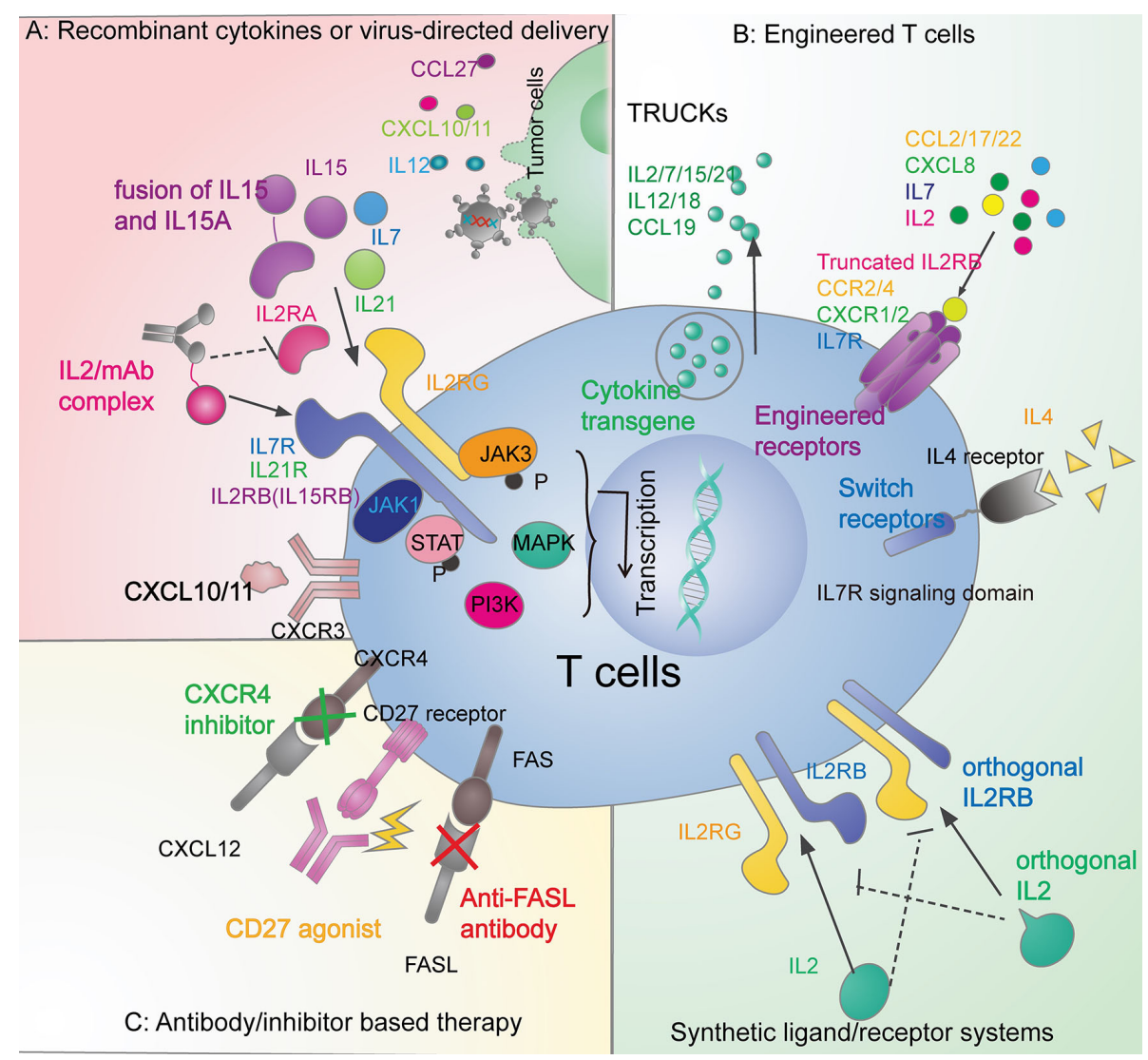

FIGURE 2 | Therapeutic strategies in overcoming the T-cell exclusion by leveraging the cytokine signals. (A) Recombinant cytokines or virus-directed delivery. Administration of recombinant IL2 (94), IL7 (95), and IL15 $(96,97)$ have brought success in clinical trials. Also, there are other recombinant cytokines under research in preclinical models, such as IL21 (98), and CXCL10 (24). Adenoviral, retrovirus, and vaccinia vectors can also deliver cytokines, including CCL27 (41), IL12 (99, 100), CXCL10 (26), and CXCL11 (25). (B) Engineered T cells. The fourth-generation CAR T cells (TRUCKs) can release IL2 family cytokines (IL2, IL7, IL15, and IL21) (101), IL12, IL18 (102) and CCL19 (103). CAR T cells can also be engineered with functional receptors such as CCR2 (30, 31), CCR4 (66), CXCR1/2 (54), IL7R (54, 104), truncated IL2B domain (105), and switch receptors to overcome the immune-suppressive cytokines (106). Tumor-specific T cells can also be equipped with synthetic ligand/receptor systems such as IL2 and IL2RB orthogonal pairs (107). (C) Antibody/inhibitor-based therapy. Agonistic (105, 108) or antagonistic (109) antibodies and inhibitors (58) are applied to modulate cytokine signaling pathways in the anticancer immune response.

melanoma patients (143). However, reasons preventing IL2 from extensive clinical usage include short half-life in vivo (144) and severe toxicity at therapeutic dosage (145). Another barrier is that not only newly-activated CD8 T cells but also Tregs can express the trimeric high-affinity receptor IL-2R $\alpha \beta \gamma$ (IL2RA+B+G complex) for IL2 signaling (116).

Several methods may attenuate IL2's propensity to promote Tregs expansion (146). Besides binding to IL-2R $\alpha \beta \gamma$, IL2 can stimulate naive and memory $\mathrm{T}$ cells expressing an intermediate affinity receptor IL-2R $\beta \gamma$ (IL2RB+G complex). Complexing IL2 with specific anti-IL2 antibodies will present IL2 to the intermediate ( $\mathrm{T}$ effector) but not high-affinity (Treg) receptors, thereby reducing the Tregs production and causing massive CD8+ $\mathrm{T}$ cells expansion in mice (147-149) (Figure 2A). Engineered IL2 and IL2RB orthogonal pairs, consisting of the mutant IL2 cytokine and cognate mutant receptor in an engineered T cell, may transmit IL2 signals only to transferred $\mathrm{T}$ cells without interacting with the natural counterparts (106)
(Figure 2B). Transduced CAR-T cells with a truncated IL-2R $\beta$ domain increased STAT3 and STAT5 signaling and improved the CAR-T-cell expansion in mice leukemia and melanoma model (104) (Figure 2B).

Other members in the IL2 cytokine family play a similar and synergistic role with IL2 in cancer immunity through a shared gamma chain (CD132) in their receptor and downstream JAKSTAT signaling (133). For example, unlike IL2 produced by immune cells, IL7, mainly secreted by fibroblastic reticular cells in lymph nodes, can support the survival of naive and memory $\mathrm{T}$ cells expressing the receptor IL7R. IL7-IL7R signaling regulates the proliferation of target $\mathrm{T}$ cells via up-regulation of the antiapoptotic BCL2 $(118,119)$ and suppression of pro-apoptotic mediators Bad and Bax (120). IL7 cannot trigger the expansion of Tregs because they express low levels of surface receptor IL7R. IL15 is essential for homeostasis and development of effector CD8 T cells and NK cells through interaction with its high-affinity receptor IL15RA. IL15 can also inhibit activation-induced cell 
TABLE 3 | Positive signals of T-cell survival.

\begin{tabular}{|c|c|c|}
\hline Signal/Receptor & Producer/Target & Mechanisms \\
\hline $\begin{array}{l}\text { (fn. 6) IL2/IL2RA,B, } \\
\text { G }\end{array}$ & $\begin{array}{l}\text { DC, activated T cells/ } \\
\text { effector T cell, Treg }\end{array}$ & $\begin{array}{l}\text { CD8+ T cells depend on IL2 for sustained } \\
\text { expansion (114, 115). However, the high-affinity } \\
\text { IL2RA is not only expressed on activated T cells } \\
\text { but also on Tregs, which is the primary barrier for } \\
\text { the clinical application of IL2 (116). }\end{array}$ \\
\hline IL7/IL7R+IL2RG & $\begin{array}{l}\text { Fibroblastic reticular cell/T } \\
\text { cell }\end{array}$ & $\begin{array}{l}\text { IL7 promotes the homeostasis and expansion of } \\
\text { naive and memory T cells by up-regulating BCL2 } \\
(118,119) \text {, and suppressing pro-apoptotic } \\
\text { mediators (120). }\end{array}$ \\
\hline
\end{tabular}

(fn. 8) IL10/ IL10RA+IL10RB

IL12A, IL12B/ IL12RB1 + IL12RB2
Treg, Th1, DC, macrophage, epithelial cell/Tumor-resident T-cell (122).

Phagocytic cells, B cells, $\mathrm{DC} / \mathrm{T}$ cells
IL10 directly activates and expands tumorresident $\mathrm{T}$ cells without de novo infiltration from secondary lymphoid organs (123).

IL12 stimulates activated T-cell proliferation (125). downstream JAK1, JAK3, STAT3, and STAT5, which stimulates T-cell proliferation and survival (127). IL15 inhibits AICD and maintains T cells' homeostatic proliferation.

Combined stimulation with IL 12 and IL18 can

IL18/ Activated macrophages IL18R1+IL18RAP and Kupffer cells/T cells,

IL21/IL21RA, IL2RG

CD27L/CD27 T cells/T cells

41BBL/41BB

CCL19/CCR7

CCL21/CCR7, CXCR3

cells, T cells/activated cell cell stimulate memory $T$ cells in an antigen nonspecific manner $(129,130)$.

IL12 and IL18 may synergize with each other to induce Th1 differentiation (131).

Th17, Tfh, NKT cells/T cell IL21 synergistically works with IL15 to expand CD8+ memory T cells (98). IL21 also suppresses Foxp3-expressing cells (132).

The CD27L/CD27 signaling plays an essential role in T-cell differentiation, survival, and memory T-cell formation (19, 134).

41BBL facilitates cell activation, survival, and proliferation upon binding to $41 \mathrm{BB}$ on $\mathrm{T}$ cells (137).

Fibroblastic reticular cell/T

T zone fibroblastic reticular cells can prevent the death of naive and memory $T$ cells by secreting CCL19 (139, 140).

Lymphatic vessels, stroma CCL21 promotes the expansion of naive T cells in cells, HEV in lymph tumors (141). nodes/CCR7+, CXCR3+ cells $(35,36)$
Intratumoral injection of a recombinant retrovirus vector expressing IL-12 induces antitumor and anti-angiogenic effects in murine models of head and neck squamous cell carcinoma (99) and melanoma (100). The phase I trial of (fn. 9) NHS-IL12 in metastatic or locally advanced solid epithelial or mesenchymal tumors showed enhanced antitumor activity with increasing immune cell infiltration (126).

IL15 has entered the clinical trial in patients with metastatic melanoma, renal cell carcinoma, and non-small cell lung cancer in CAR-T therapy and combination treatment with anti-PD1

antibody $(96,97,128)$.

IL-2 was one of the first FDA-approved immunotherapies for metastatic melanoma and renal cell cancer $(94,117)$, (fn. 7). Since IL2 expands effector T cells at the cost of Treg proliferation, engineered IL2 is necessary to preferentially target IL2 receptors on effector T cells (107).

Coexpressing the IL7R with CAR-GD2 T cells activates STAT5 signaling and shows super antitumor response in metastatic neuroblastoma and glioblastoma mice model (104). Clinical trials using recombinant IL7 as monotherapy showed increases in CD4 and CD8 T cells with a decrease in Tregs in multiple cancer types 121)

reatment with pegylated IL10 restores tumor-specific CD8 T-cell accumulation and controls tumor growth in mice (124).

The combined administration of IL21 and IL15 dramatically increased the CD8+ T cells and resulted in tumor regression in mice melanoma models (98). Likewise, the combination treatment of IL21 with IL7 promotes the expansion of CAR-T cells with a TSCM phenotype (133).

CD27 agonist showed antitumor efficacy in mice models (135) and phase I and || clinical trials of advanced solid tumors (108, 136), 41BBL armored CAR T-cells showed enhanced in-vitro and invivo efficacy (138).

CCL19 CAR-T achieved superior antitumor activity compared to conventional CAR-T in mice (103).

Delivery of CCL21 to metastasis tumors enhances the ACT efficacy by promoting the T-cell survival and cytotoxic activity in mice (142). death (AICD), further facilitating the proliferation of CD8 T cells (150). IL21, produced by T helper 17 (Th17), follicular helper T cells (Tfh), and NKT cells, drives NK expansion and differentiation (133). Also, IL21 inhibits Treg survival by downregulating the FOXP3 expression and favors the development of antigen-specific cytotoxic T cells (132).

In contrast to IL2, other IL2-family cytokines IL7, IL15, and IL21 do not induce Treg expansion. The role of these cytokines in modulating $\mathrm{T}$ cell-based cancer immunotherapies is currently being explored. Administration of recombinant IL7 alone showed a dose-dependent increase of $\mathrm{T}$ cells along with a decrease of Tregs in patients with lymphopenia (95). In clinical trials, human IL15 as monotherapy promoted proliferation of circulating NK cells and CD8 $\mathrm{T}$ cells in patients with metastatic melanoma and renal cancer, with the cost of severe toxicity at the therapeutic dose (96). Combined administration of IL15 and IL21 had synergistically accelerated the growth of both naive and memory CD8 T cells and resulted in tumor regression in a murine model of melanoma. IL21 has also demonstrated cooperative effects with IL7, but not IL2 (98).

Treatment of IL2-family cytokines in combination with TILs, CAR-T, and checkpoint blockade can lead to a broader and stronger antitumor response. Fourth-generation CAR-T cells armed with 
inducible cytokines have been defined as $\mathrm{T}$ cells redirected for universal cytokine-mediated killing (TRUCK) (Figure 2B). TRUCKs, loaded with IL2 family cytokines, enhance the persistence of CAR-T cells for antigen-specific tumor killing, and activate innate immune cells for antigen-negative tumors killing (101).

Besides the IL2 family, IL12 and IL18 secretion by TRUCKs have also been tested $(151,152)$. IL12 and IL18 can promote the activation and expansion of memory CD8 T cells in an antigenindependent manner (101). TRUCKs with inducible IL12 have dual antitumor activity. Firstly, the activated TRUCKs will lyse tumor cells and secret IL12 upon CAR engagement. Then, the locally released IL12 will not only promote CAR-T cells activation in an autocrine manner but also activate and recruit the innate immune cells (such as NK cells and macrophages) to kill tumor cells without antigens (102). Intratumoral administration of IL12 had antitumor effects in murine models of head and neck carcinoma (99) and melanoma (100). There are advantages of inducible production of IL12 (triggered by CAR signaling) over constitutive IL12 delivery at the tumor sites. As long as the TRUCKs are engaged and stay activated, there will be induction and secretion of IL12 for durable tumor control. It is important to note that the safety of TRUCKs is a concern since cytokine release syndrome happens in most CAR-T therapy (153).

Several cytokines, such as CD27L and 41BBL, which belongs to the tumor necrosis factor family, also act as costimulatory signals for $\mathrm{T}$ cells. CD27L is only transiently expressed on activated immune cells. However, the CD27L-CD27 costimulation bolsters T-cell activation, proliferation, and differentiation to a memory T-cell phenotype, thus enhancing anticancer immunity $(134,154)$. Targeting the CD27L-CD27 axis might be a therapeutic strategy given the observation that patients with $\mathrm{CD} 27 \mathrm{~L}$ or CD27 mutations and deletions are at a higher risk of developing Hodgkin lymphoma (155). Varlilumab, an anti-CD27 monoclonal agonistic antibody, showed clinical efficacy in a phase I study of refractory solid tumors (109). A combination of Varlilumab with checkpoint blockade therapy also established early success in phase I and II clinical trials (136).

The 41BBL-41BB signal's importance is underscored by the observations that agonistic antibodies against $41 \mathrm{BB}$ can significantly promote CD8 T cells expansion and decrease T cells apoptosis, contributing to a robust antitumor immunity in mice $(157,158)$. However, the low efficiency (Utomilumab) (157) and liver toxicity (Urelumab) (158) severely hampered the clinical application of $41 \mathrm{BB}$ antibodies. The most remarkable clinical benefit of $41 \mathrm{BB}$ so far comes from the FDA-approved CAR-T cells containing $41 \mathrm{BB}$ as the intracellular costimulatory domain. The second-generation CAR-CD19 T cells armed with 41BBL have shown notable antitumor responses in several clinical trials against B-cell acute lymphoblastic leukemia $(159,160)$.

Interestingly, chemokines may sometimes enhance CD8 T cells' survival and propagation apart from acting as chemoattractants. Both CCL19 and CCL21 can promote naive T cells' survival (161). Secondary lymphoid organs are primary sources for CCL19 and CCL21, and access to the secondary lymphoid organs is crucial for naive T cells survival (139). Intratumoral delivery of CCL21 augmented the tumor-killing efficacy of adoptive cell therapy (ACT) in a murine model of melanoma by promoting T-cell survival rather than recruitment (142). IL10 can also induce the activation and multiplication of tumor-resident $\mathrm{T}$ cells without trafficking from the secondary lymphoid organs. IL10R, expressed on CD8 T cells, is necessary for the IL10-mediated tumor regression and the in-situ proliferation of CD8 T cells (123). However, given the suppressive function of IL10 during the T-cell priming and IL10-induced T cells exhaustion $(162,163)$, the value of IL10 as a therapeutic target needs further investigation.

\section{Signals Triggering T-Cell Apoptosis}

There are various cytokine-mediated mechanisms by which the hostile TME triggers T-cell apoptosis (Table 4). The best-known one is through activation-induced cell death (AICD). AICD is a process that occurs when CD8 T cells express high FAS and FAS ligand (FASLG) expression levels upon activation, triggering the apoptosis of neighboring CD8 T cells (176). The binding of FAS to FASLG will recruit the FAS-associated death domain (FADD) to the intracytoplasmic death domain (IDD) of the receptor and initiates the caspase 8 activation and the subsequent cascade caspases (177). IL1, IL6, and TNF can also promote FAS and FASLG expression $(178,179)$. Moreover, the tumor endothelium can release FASLG, leading to apoptosis of T cells when they are trying to transmigrate the tumor vessel (69). Also, tumor-derived VEGF, IL10, and PGE2 can all enhance the FASLG expression (69). Notably, the endothelium-dependent apoptosis hardly works for Tregs because of the activation of anti-apoptotic molecules like BCL2 and CFLAR in Tregs $(69,180)$. An ovarian cancer study confirmed that the endothelium secreting FASLG induces deficient CD8 T cells infiltration and a predominance of Tregs (69).

Given the immune-suppressive role of FAS-FASLG signaling, different approaches to inhibit FASLG have been tested. For example, treatment with FASLG-neutralizing antibody (Figure 2C) markedly reduced $\mathrm{T}$-cell apoptosis and cancer cell migration in a glioblastoma mouse model (109). Genetically engineered T cells with disruption of FAS-FASLG signaling introduced by adoptive T-cell transfer dramatically prevented FASLGmediated T-cell apoptosis and achieved superior persistence in murine models (167).

Besides FASLG, other death receptors may mediate T-cell apoptosis when triggered by their cognate ligands, such as TNFRSF10A (TRAIL-R1, DR4), TNFRSF10B (TRAIL-R2, DR5), TNFRSF25, TNFRSF1A (TNFR1), and TNFRSF1B (TNFR2). Theoretically, the TNF-related apoptosis-inducing ligand (TRAIL) cannot induce apoptosis of T cells since T cells express low levels of TRAIL-R1/2, which contains the cytoplasmic death domain. TRAILR1/2 may recruit FADD, activates caspase 8 , and leads to T-cell apoptosis upon binding to TRAIL (181). Interestingly, there was an observation that CAR-T cells did undergo programmed cell death triggered by the FAS-FASLG and TRAIL-DR5 pathway. Also, ex vivo combined blockade of FAS and TRAIL signaling significantly rescued the CAR-T cells $(169,170)$.

TNF receptors are also critical death receptors for activated T-cell apoptosis. Soluble and membrane-bound TNF bind to different receptors to trigger apoptosis. Upon activation, TNFR1 
TABLE 4 | Negative signals of T-cell survival.

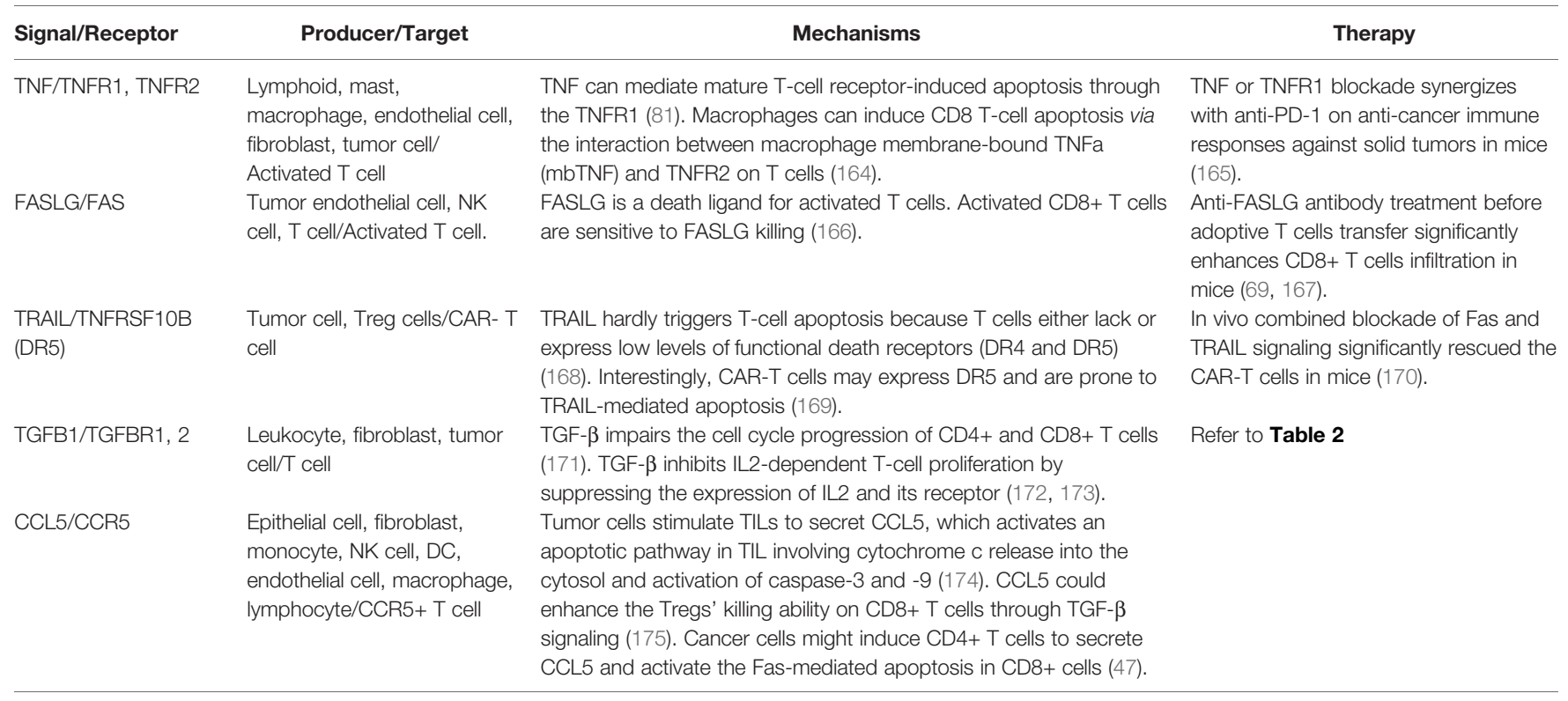

can either trigger cell apoptosis via the formation of FADD-IDD complex leading to caspase cascade activation or induce the proliferation pathway through NFkB activation. A study showed that T-cell depletion occurs in mice with FAS and FASLG defects. The inhibition of both FAS and TNF is necessary to eliminate T-cell death, and the TNF-TNFR1 signal mediates most CD8 T cells apoptosis (182). Macrophages can also induce apoptosis of CD8 T cells via the interaction between macrophage membrane-bound TNF and TNFR2 on T cells (164). Notably, MDSCs and Tregs also express TNFR2, whose activation will trigger the proliferation through NFkB signaling pathway instead of apoptosis in these cells (183).

Other mechanisms within the tumor microenvironment resulting in T-cell apoptosis include depletion of tryptophan by indoleamine-2,3-dioxygenase (IDO) and generation of Galectin 9, both of which binds to TIM3, which are predominantly mediated by immune-suppressive cells such as Tregs and MDSCs. Unexpectedly, chemokines can sometimes trigger non-classic apoptosis signals in T cells. TILs-secreted CCL5 induces CCR5+ (CCL5 receptor) $\mathrm{T}$ cells death through the release of cytochrome $\mathrm{c}$ from mitochondria and activation of caspase- 3 and 8 (174). CCL5, secreted by tumor-infiltrating CD4 $\mathrm{T}$ cells, also facilitates the FAS-FASLG mediated CD8 T-cell apoptosis in gastric cancer (47).

\section{T-CELL DIFFERENTIATION: T CELLS MANAGE TO KEEP IN THEIR PROPER STATES FOR DURABLE FIGHTING}

\section{CD8 T Differentiation in Tumors}

T-cell differentiation pathway is one of the primary factors determining $\mathrm{T}$ cells' prolonged tumor-killing activity. Upon exposure to the cognate tumor-antigens, activated CD8 T cells will differentiate from a naive state into effector $\mathrm{T}$ cells. There are disputes regarding the differentiation track of CD8 T cells. The de-differentiation model purports that naive $\mathrm{T}$ cells are directly programmed into short-lived terminal effector $\mathrm{T}$ cells, followed by de-differentiation into memory cells with increased longevity $(184,185)$. Weissman and colleagues suggested that naive T cells differentiate along a sequential lineage path into stem-cell memory cells (TSCM), central memory cells (TCM), effector memory cells (TEM), and the terminally differentiated effector cells (184) (Figure 1C).

As terminal differentiation proceeds, $\mathrm{T}$ cells lose their selfrenewal ability, proliferative potential, and lifespan $(184,186)$. The adoptive transfer of TSCM enhanced antitumor responses compared with TCM and TEM subsets in a humanized mouse model of mesothelioma (187). Given the superior anticancer efficacy of memory CD8 T cells, people have developed various T-cell selection methods for ACT, such as epigenetic and genetic modification $(186,188)$, reprogramming of induced pluripotent stem cells (189), and cytokine treatment.

The IL2 family members exert their specific roles in CD8 Tcell differentiation and proliferation (Table 5). IL2 drives terminal effector $\mathrm{T}$ cells differentiation and proliferation by upregulating perforin, granzyme B and IFN- $\gamma$ and suppressing the memory cell marker BCL6 and IL7RA (199). On the contrary, IL7, 1L21, and IL15 may promote the memory cell phenotype. IL7 can generate TSCMs from their naive precursors $(200,201)$. CAR-T therapies frequently require IL7 during the ex-vivo expansion phase (202). For example, CAR-CD19 T cells cultured in vitro with IL7 and IL15 significantly induced a TSCM phenotype and produced a robust response against B-cell malignancies in phase I clinical trial (203). TRUCKs with constitutive IL7R signaling increased T-cell proliferation, survival, and tumor-killing activity upon exposure to tumor antigens, without stimulating bystander lymphocytes in murine cancer models (103). 
TABLE 5 | Positive signals of T-cell effector activity through differentiation.

\begin{tabular}{|c|c|c|c|}
\hline Signal/Receptor & Producer/Target & Mechanisms & Therapy \\
\hline IL7/IL7R+IL2RG & $\begin{array}{l}\text { Fibroblastic reticular cell/CD8 T } \\
\text { cell }\end{array}$ & $\begin{array}{l}\text { IL-7 generated the stem-cell memory T cells from naive CD8 T cells } \\
\text { (150). }\end{array}$ & \\
\hline IL12A,B/IL12R & Phagocytic cells, B cells, DC/ & IL12 and IFN- $\alpha / \beta$ provide a third signal, along with Antigen and & \\
\hline IFN- $\alpha / \beta /$ IFNAR1, 2 & CD8 T cells & $\begin{array}{l}\text { costimulation, to support CD8 T memory programming, which involves } \\
\text { chromatin remodeling and regulation of genes such as TBX21 (T-bet) } \\
\text { and EOMES (190, 191). IL12 also polarizes naive T cells into Th1 cells } \\
\text { (192). }\end{array}$ & \\
\hline $\begin{array}{l}\text { IL15/IL15RA, IL2RB, } \\
\text { IL2RG }\end{array}$ & $\begin{array}{l}\text { Monocytes, macrophages, DC/ } \\
\text { CD8+ T cells }\end{array}$ & IL15 induces the generation of antigen-specific memory T cells (193). & \\
\hline IL21/IL21R+IL2RG & Th2, NKT cells/CD8 T cell & $\begin{array}{l}\text { IL21 suppresses the antigen-induced CD8+ T-cell differentiation from } \\
\text { naive T cells to effector T cells and induced stem-like properties, which } \\
\text { allows CD8+ T cells for secondary expansion after adoptive transfer } \\
\text { (194). }\end{array}$ & \\
\hline CD40L/CD40 & $\begin{array}{l}\text { DC, macrophages, B cells, T } \\
\text { cells, mast cells/CD40+ T cell }\end{array}$ & $\begin{array}{l}\text { CD40L/CD40 increases T-cell proliferation, CD8+ T-cell immunity, and } \\
\text { memory (195). }\end{array}$ & \\
\hline TGFB+IL6+IL23 & In-vitro culture treatment. & $\begin{array}{l}\text { CD4+ T-cell differentiates into Th17 via TGFB and IL6 (196). IL23 } \\
\text { maintains the proliferation of Th17. (Fn. 10) Th17 are long-lived cells with } \\
\text { stem-like properties. It can also convert into a Th1-lineage over time, } \\
\text { switching from IL17 secreting cells to IFN } \gamma \text { producers or IFN } \gamma / \text { IL17A } \\
\text { double producers (197). }\end{array}$ & $\begin{array}{l}\text { Transfer of Th17 cells } \\
\text { enhances survival and tumor } \\
\text { regression better than Th1 } \\
\text { cells in a murine melanoma } \\
\text { model (198). }\end{array}$ \\
\hline CCL21/CCR7, CXCR3 & $\begin{array}{l}\text { Lymphatic vessels, stroma cells, } \\
\text { HEV in lymph nodes/CD4 T cells } \\
(35,36)\end{array}$ & CCL21 promotes Th1 polarization (141). & \\
\hline
\end{tabular}

Antigen-presenting cells secret IL15 bound together with its high-affinity receptor IL15RA (204). The signal will reach target cells that express IL-2R $\beta \gamma$, including CD8 memory T cells. ALT803, a fusion complex of IL15 and IL15RA receptor, exhibited a more substantial tumor-killing effect than native IL15 in preclinical models of myeloma through promoting the proliferation of CD8 memory $\mathrm{T}$ cells and inducing large amounts of IFN- $\gamma$ (205). Administration of ALT-803 combined with anti-PD1 antibody showed tumor-killing effects in non-small cell lung carcinoma patients who failed the anti-PD1 monotherapy (97).

IL21 augments ACT therapy by preserving $\mathrm{T}$ cells in a younger phenotype but at the cost of less expansion than those expanded with IL2. However, adoptive T cells stimulated with IL21 induced a more robust antitumor response in a murine melanoma model (206). Similarly, IL21 treatment has generated TRUCKs with a more naive phenotype. When transferred into the host, these TRUCKs showed a dramatic propagation upon tumor exposure and achieved improved tumor control (194).

A study compared the therapeutic efficacy of CD19-specific TRUCKs equipped with IL2, 7, 15, and 21 expression cassettes in a murine lymphoma model. The result claimed that IL7 and IL21 were superior to IL2 and IL15 in enhancing tumor eradication, although IL2 and IL15 established increased effector functions. Interestingly, IL21 overexpression best supported the long-term persistence of memory $\mathrm{T}$ cells, while IL7-transduced T cells expanded to the greatest extent upon secondary antigen presentation (207). The varying roles of IL2 family members suggest that combinatorial approaches are necessary for ideal $\mathrm{T}$ cells-based therapy.

Other cytokines also contribute to CD8 T cell memory programming (Table 5). For example, the generation of memory cells needs signals from CD4 Thelper cells. The interaction between CD40 expression on CD8 T cells and CD40 ligand (CD40L) expression on CD4 T cells is indispensable for the helper process. However, the CD40L/CD40 signal is not necessary for naive CD8 T cells to differentiate into terminal effector cells (195). IL12 and type I IFN (IFN- $\alpha / \beta)$ provide a third signal in concert with antigen presentation and costimulation to establish long-term memory CD8 $T$ cells. IL12 and IFN- $\alpha / \beta$ promoted the memory program of naive CD8 T cells mainly through chromatin remodeling, which involved histone acetylation of genes like EOMES, TBX21, and GRZB (190). In addition, CD4 T helper cells provide a CD40CD40L stimulus for DCs to produce IL12, promoting the CD8 T cell memory program $(190,209)$.

\section{Functional Fate of CD4 T-Cell Subsets in Tumors}

Unlike CD8 T cells, the differentiation of CD4 T cells is divergent. CD4 $\mathrm{T}$ cells differentiate into various $\mathrm{T}$ helper (Th) cell and regulatory (Treg) cell lineages to exert their functions in the tumor immunity. Upon exposure to different lineage-determining cytokines during activation, naive CD4 T cells may have several distinct effector fates, such as Th1, Th2, Th17, Treg, and Tfh (Table 5 and Figure 1C). Besides supporting CD8 T cells, CD4 T cells may directly lyse tumor cells in an MHC-II dependent manner through the secretion of perforin and granzyme $(209,210)$. A recent study demonstrated the occurrence of clonal expanded cytotoxic CD4+ T cells by single cell sequencing, these CD4 T cells possessed lytic capabilities against autologous tumors (210). Multiple studies have identified several origins of CD4 cytotoxic T cells, such as Th2, Th17 and Treg (211). However, the majority of CD4 CTL are thought to come from IFN- $\gamma$ secreting Th1 cells (212).

Each of the CD4 $\mathrm{T}$ subsets has a specific role in antitumor immunity by producing and receiving distinct cytokines. Th1 can provide IFN- $\gamma$, TNF, CCL 2 and CCL3 to enhance the recruitment of CD8 T cells, NK cells and anticancer macrophages (213-216). 
Cytokines IFN- $\gamma$, IL12, IL18, IL27 can promote Th1 polarization, thus contributing to tumor control $(141,192)$. However, the role of Th2 cells in the tumor immunity is contradictory and contextdependent. IL4 is both the inducer of Th2 polarization (Table 6) and the effector cytokines secreted by Th2. IL4 has an immunesuppressive role by antagonizing the Th1 response and supporting Tregs (219). CAR-T cells engineered to overcome the immunesuppressive nature of IL 4 have brought early success. CAR-MUC1 $\mathrm{T}$ cells with an inverted IL4 receptor exo-domain plus an IL7 receptor signal endo-domain (Figure 2B) facilitated a potent antitumor response in a mouse model of breast cancer with an abundance of IL4 in the tumor milieu (106). Th2 may also promote angiogenesis and hinder apoptosis of tumor cells by remodeling the cytokine environment for macrophages and eosinophils infiltration (220). However, some studies have demonstrated the antitumor activity of Th2 cells by recruiting the innate cells such as eosinophils to the tumor (221).

The signals of TGF $\beta$ and IL10 polarize naive CD4 T cells to Tregs (Table 6). Tregs have been regarded as exerting suppression roles in antitumor immunity and high Treg/CD8 ratio in tumor infiltrates correlates with poor prognosis in cancer patients (222). However, recent study showed that IFN- $\gamma$ production by Tregs is necessary for the therapeutic responses of anti-PD1 in a mice model, which shed light on characterizing the contribution of IFN$\gamma+$ Tregs in tumor immunotherapy (223).

Naive CD4 T cells can also differentiate into Th17 cells with stimulation by TGF $\beta$ and IL6 and maintenance with IL23. Characterized by the high production of IL17 and IL22, Th17 cells have a controversial role in the cancer immunity context. Th17 cells may stimulate angiogenesis and promote tumorigenesis. However, these cells also serve as tumor-suppressive cells by stimulating effector CD8+ T cells, supporting immune cell recruitment, and transitioning to Th1-lineage over time (224). Moreover, Th17 cells possess long-lived memory-like properties through the expression of stem-cell markers such as CCR7, LEF1, and TCF7 (225). Thus, the adoptive transfer of Th17 polarized CAR-T cells had been shown to produce superior tumor regression than Th1 cells in mice $(225,226)$. Follicular helper (Tfh) T cells characterized by IL21 secretion have been shown to contribute to antitumor responses by promoting the formation of intratumor follicular structures, which were positively associated with prognosis of cancer patients $(227,228)$.

Since the cytokine environment is pivotal in fate-determination of naive CD4 T cells, manipulation of CD4 T cells using cytokine signals has provided substantial promise in therapy. For example, Th17 polarized cells in cell culture with TGF $\beta$, IL6, and anti-IFN- $\gamma$ antibody (preventing Th1 differentiation) mediated effective tumor eradication and a survival advantage in a murine melanoma model (198). However, the lifetime of CD4 T cells generated is very short, and many other cytokines are necessary for their maintenance, which represents a significant barrier for use in clinical applications (229). Robust methods are still lacking for generating effector CD4 T subtypes with stem-like properties and longevity.

\section{CYTOKINE RELEASE SYNDROME: EVERY COIN HAS TWO SIDES}

As reviewed in previous sections, many therapies modulate cytokine and chemokine signaling to overcome the T-cell exclusion barriers in tumors (Figure 2). However, a danger of cytokine-based treatments is the severe toxicity from cytokine release syndrome (CRS). CRS is the over-activation of the immune system characterized by a flood of inflammatory cytokines, fever, and multiple organ dysfunction (230). CRS can happen after administration of therapeutic monoclonal antibodies or cytotoxic chemotherapies, such as the CD28 agonist TGN1412 (231), Rituximab and Obinutuzumab (targeting CD20) (232, 233), Dacetuzumab (targeting CD40) (234), Nivolumab (anti-PD1) (235), Oxaliplatin (236), and Lenalidomide (237).

Moreover, T-cell therapies, such as CAR-T and TCR-T cells, the bispecific T-cell (BiTE) single-chain antibody, and the dualaffinity re-targeting antibody, have produced the high CRS frequencies (238). CRS happens in nearly all CAR-T clinical trials, with presentations ranging from mild symptoms such as fever to life-threatening manifestations, including sepsis, thromboembolism, neurotoxicity, and multi-organ failure (230, 239). However, there is no conclusive evidence connecting the CRS severity to the immunotherapy response, and complete tumor remission can happen in patients without CRS (240).

The exposure of CAR-T cells to a tumor antigen can trigger CRS. The activation and proliferation of CAR-T cells release primary cytokines such as IL1, IFN- $\gamma$, and TNF, which induce the activation of other immune cells, such as macrophages, DCs, and monocytes (241). These cells then produce excessive amounts of secondary cytokines, such as IL6, IL10, and IL5 (242). Among these cytokines, IL6 is a crucial regulator of CRS and contributes to critical symptoms (243). The IL6/IL6R complex binds to the membranebound IL6ST (gp130) and activates a cascade of intracellular signaling, which results in severe CRS (244).

Several clinical factors are potentially predictive of the CRS severity. The first factor is the tumor burden. In many observations, the most severe CRS only occurs after the first

TABLE 6 | Negative signals of T-cell effector activity through differentiation.

\begin{tabular}{|c|c|c|c|}
\hline Signal/Receptor & Producer/Target & Mechanisms & Therapy \\
\hline $\begin{array}{l}\text { (fn. 11) IL4/ } \\
\text { IL4R+IL2RG }\end{array}$ & $\begin{array}{l}\text { Th2, basophils, eosinophils, mast } \\
\text { cells, NKT cells, Adipose tissue, } \\
\text { cancer cells/Th1 }\end{array}$ & $\begin{array}{l}\text { (fn. 12) IL4 drives CD4+ T-cell } \\
\text { polarization into the Th2 phenotype } \\
\text { and suppresses IFN } \gamma \text {-producing Th1 } \\
\text { cells (217). }\end{array}$ & $\begin{array}{l}\text { MUC1 CAR T with a cytokine switch receptor of IL4 receptor } \\
\text { extracellular domain fused to an IL7 intracellular signaling domain } \\
\text { can proliferate and suppress tumor growth in mice breast cancer } \\
\text { model (106). }\end{array}$ \\
\hline TGFB1/TGFBR1,2,3 & Leukocyte, fibroblast, tumor cell/ & TGF $\beta$ promotes the conversion of & \\
\hline
\end{tabular}
CD4 T cell effector T cells to Tregs (218). 
administered dose, and will not occur during the subsequent therapies, called the first-dose effect. It is believed that the first-dose effect is due to the high tumor antigen load at the initiation of treatment (245). The administered dose of an agent is another factor (246). The maturation of the immune system may be another factor for CRS because children are more likely to develop severe CRS following CD19 CAR-T-cell infusion in clinical trials. Also, the type of T-cell engaging agents affects the onset, duration, and severity of CRS (160). For example, first-generation of CAR T cells hardly triggered the CRS because of the lack of a costimulatory domain. Among the second-generation CAR-T cells (247), CARs with CD28 costimulation have a higher CRS rate than those containing a $41 \mathrm{BB}$ co-stimulation (248). Before CAR-T infusion, the lymphocyte depletion type also affected the risk, with a higher CRS incidence observed after fludarabine-based lymphodepletion (249).

The principle of CRS management is to prevent life-threatening toxicity and preserve the maximum antitumor immune responses. Low-grade CRS can be treated symptomatically with antipyretics and fluid therapy. As for severe CRS, in the BiTE blinatumomab context, some clinical trials advised the usage of corticosteroids to reduce the CRS incidence (250). Because clinicians can give BiTE repeatedly, immediate action can be taken upon CRS manifestation, even at the cost of lowering the antitumor response. However, unlike BiTE, the manufacture of CAR T cells allows only limited amounts for one-time administration. Therefore, corticosteroids should be avoided at the first-time treatment of CRS in patients receiving CAR T therapies, unless severe neurotoxicity has developed.

IL6 levels are significantly higher in the serum of patients with severe CRS after CAR-T treatment. IL6 and IL6 receptors are attractive targets for CRS treatment because IL6 is less critical for T-cell function than other inflammatory cytokines. The FDA approved Tocilizumab (monoclonal antibodies against IL6R) to treat severe CRS in patients who are at least two years old (251). For patients who are unresponsive to anti-IL6 or IL6R treatment, other ongoing clinical trials are evaluating $\mathrm{T}$ cell-depleting antibodies, such as Alemtuzumab, IL-1R-based inhibitors (Anakinra), and Ibrutinib $(252,253)$.

\section{CONCLUSIONS AND FUTURE DIRECTIONS}

The systematic categorization of cellular signaling mechanisms that modulate the T-cell infiltration, survival, and differentiation in tumors is the premise of overcoming the T-cell exclusion barriers. However, many cytokines have both positive and negative effects on the anticancer immune response depending on their different receptor usage, cellular context, and interactions with other signals. Meanwhile, cytokines promoting the T-cell functions may also induce the life-threatening cytokine release syndrome without clear indicators. Given a large number of signaling molecules and the intricate crosstalks among them, it remains a significant challenge for the field to gain a comprehensive view of the complicated immune ecosystem.

Leading-edge technologies such as single-cell omics and spatial genomics have enabled the profiling of the tumor microenvironment at high dimensions. Many of these new technologies, coupled with computational models, can reveal the cytokine and chemokine activities through the molecular status of their downstream signaling pathways. Meanwhile, the rapid development of automated technologies has enabled the large-scale screening of immunological assays in preclinical models. Catalyzed by recent technological advances, we foresee rapid knowledge growth on cytokines and chemokines.

Only two cytokines interferon-alpha and IL2 have been approved by the FDA for treatment of refractory melanoma and renal cell cancer, and are rarely used as monotherapy. Bottlenecks in the therapeutic application of cytokine therapies include the dose-limiting toxicity, the short half-life in the circulation, the low concentration at tumor sites when administered intravenously, and the unwanted recruitment of immune suppressive cells. Advancements in delivery technologies have shown encouraging safety and efficacy in preclinical models. For example, smart nanocarriers can respond to multiple stimuli in the blood circulation and tumor by changing their physical and chemical properties for precise and lasting cytokine release $(254,255)$.

$\mathrm{T}$ cells armed with stimulatory cytokines have great potential to remodel the suppressive tumor microenvironment. However, there remains a need to generate "smarter" $\mathrm{T}$ cells, given the multiple suppressive signals in tumors, the inter-and intra-tumor heterogeneity, and potential severe toxicities of current $\mathrm{T}$ cellbased therapies. Modern gene-editing technologies can encode immunomodulatory fusion proteins in $\mathrm{T}$ cells to rewire the inhibitory or death receptor signaling. Such engineered T cells should sense the host environment and react to different cues in a precise manner. The synthetic Notch receptors could serve as a versatile platform for engineered T cells. Activation of Notch and the intracellular transcriptional signal upon the customized antigen sensing should trigger production of a specific cytokine profile (256).

Given the complexity of tumor heterogeneity, it is unlikely that one therapeutic solution is sufficient to overcome the T-cell exclusion barriers in tumors. We foresee that future successful treatments will leverage rational combinations among different therapy modules after elucidating specific cytokine activities in patient samples through high-resolution genomic technologies.

\section{AUTHOR'S NOTE}

1. IL6 has a dual function in the tumor microenvironment. It has a dark face that acts on tumor cells through multiple intrinsically downstream mediators to support cancer cell proliferation, survival, and metastatic dissemination. IL6 also works on other cells within the tumor stroma, promoting angiogenesis and tumor evasion (17).

2. TNF plays a dual role in cancer immunity, TNF induced Tcell adhesion is ICAM1 and VCAM1 dependent, and most of the chemo-attracted cells are Tregs $(257)$, Bregs $(258,259)$ and MDSC (259), which are negative modulators of the immune response. TNF also triggers the activation-induced cell death of 
CD8 T lymphocytes (Table 4) and impairs tumor infiltration by CD8 T lymphocytes (Table 2).

3. CCL5 has a tumor-promoting role by inducing tumor cell proliferation (260), angiogenesis, and matrix metalloproteinases (47). It also suppresses the antitumor immune response by increasing the recruitment of TAM and Treg in tumors (63). Moreover, it stimulates the apoptosis of CD8 T cells (Table 4).

4. The IL35 receptor components vary by cell type. In T cells, IL-35 binds IL6ST (gp130) and IL12Rß2. In B cells, IL35 signals through IL12R $\beta 2$ and IL27RA (WSX-1) $(5,261)$.

5. CXCL8 has a tumor-supporting role by activating the epithelial-mesenchymal transition (262), promoting angiogenesis $(262,263)$, and stemness potential (264).

6. IL2 and IL15 share the $\beta$ and $\gamma$ components of their receptors and have similar functions on $\mathrm{T}$ cells, including stimulating proliferation of cytotoxic T lymphocytes. However, IL2 promotes terminal differentiation and elimination by AICD (265), but IL15 inhibits AICD and promotes the generation of long-lived stem memory $\mathrm{T}$ cells and maintains homeostatic proliferation (266). Other cytokines sharing the same $\gamma$-chain in their receptors (defined as the $\gamma c$ cytokine family) include IL4, IL7, IL9, and IL21 (150).

7. Reasons that prevent the extensive usage of IL2 for cancer therapy include short half-life in vivo (144), severe toxicity at therapeutic dosage (145), and propensity to promote Treg proliferation (146).

8. Treg-derived IL10 drives the exhaustion of CD8 T cells in tumors through the up-regulation of several inhibitory receptors (PD1, LAG3, and TIGIT) via a BLIMP1 dependent pathway (162). IL10 also inhibits the activation of CD8 T cells by decreasing antigen sensitivity (163).

9. NHS stands for the antibody NHS76 against DNA released by necrotic tumor cells.

10. Th17 is a double-edged sword in anticancer immunity. It may secrete high levels of the characteristic cytokine IL17 to

\section{REFERENCES}

1. Jiang P, Gu S, Pan D, Fu J, Sahu A, Hu X, et al. Signatures of T cell dysfunction and exclusion predict cancer immunotherapy response. Nat Med (2018) 24:1550-8. doi: 10.1038/s41591-018-0136-1

2. Van Allen EM, Miao D, Schilling B, Shukla SA, Blank C, Zimmer L, et al. Genomic correlates of response to CTLA-4 blockade in metastatic melanoma. Science (2015) 350:207-11. doi: 10.1126/science.aad0095

3. Pluhar GE, Elizabeth Pluhar G, Pennell CA, Olin MR. CD8 T Cell-Independent Immune-Mediated Mechanisms of Anti-Tumor Activity. Crit Rev Immunol (2015) 35:153-72. doi: 10.1615/CritRevImmunol.2015013607

4. Bonaventura P, Shekarian T, Alcazer V, Valladeau-Guilemond J, ValsesiaWittmann S, Amigorena S, et al. Cold Tumors: A Therapeutic Challenge for Immunotherapy. Front Immunol (2019) 10:168. doi: 10.3389/fimmu.2019.00168

5. Kourko O, Seaver K, Odoardi N, Basta S, Gee K. IL-27, IL-30, and IL-35: A Cytokine Triumvirate in Cancer. Front Oncol (2019) 9:969. doi: 10.3389/ fonc.2019.00969

6. Vilgelm AE, Richmond A. Chemokines Modulate Immune Surveillance in Tumorigenesis, Metastasis, and Response to Immunotherapy. Front Immunol (2019) 10:333. doi: 10.3389/fimmu.2019.00333

7. Vilgelm AE, Andrew Johnson C, Prasad N, Yang J, Chen S-C, Ayers GD, et al. Connecting the Dots: Therapy-Induced Senescence and a TumorSuppressive Immune Microenvironment. JNCI: J Natl Cancer Institute (2016) 108(6):djv406. doi: 10.1093/jnci/djv406 stimulate angiogenesis and tumorigenesis. In contrast, Th17 may stimulate the effector CD8 $\mathrm{T}$ cells as a tumor-suppressive factor (224).

11. IL4 exerts controversial functions based on cancer types. In breast cancer, It promotes tumor growth by suppressing the effector function of Th1-polarized T cells (267). However, it drives the survival of $\mathrm{B}$ cell and $\mathrm{T}$ cells in other cancer types and promotes the long-term development of CD8 T memory cells (217).

12. Some studies demonstrated the antitumor activity of Th2 cells in collaboration with tumor-infiltrating granulocytes (268).

\section{AUTHOR CONTRIBUTIONS}

YZ and PJ outlined the review structure, finished the literature survey, and wrote the manuscript. X-yG participated in the discussion. All authors contributed to the article and approved the submitted version.

\section{FUNDING}

The work is sponsored by the NIH intramural research program and Bau Tsu Zung Bau Kwan Yeu Hing Research and Clinical Fellowship from the University of Hong Kong.

\section{ACKNOWLEDGMENTS}

We acknowledge the NIH Fellows Editorial Board for their language editing service. We also acknowledge suggestions from Dr. James Kochenderfer on our manuscript.

8. Gu-Trantien C, Migliori E, Buisseret L, de Wind A, Brohée S, Garaud S., et al. CXCL13-producing TFH cells link immune suppression and adaptive memory in human breast cancer. JCI Insight (2017) 2(11):e91487. doi: 10.1172/jci.insight.91487

9. Gentles AJ, Newman AM, Liu CL, Bratman SV, Feng W, Kim D, et al. The prognostic landscape of genes and infiltrating immune cells across human cancers. Nat Med (2015) 21:938-45. doi: 10.1038/nm.3909

10. Masopust D, Schenkel JM. The integration of $\mathrm{T}$ cell migration, differentiation and function. Nat Rev Immunol (2013) 13:309-20. doi: 10.1038/nri3442

11. Slaney CY, Kershaw MH, Darcy PK. Trafficking of T Cells into Tumors. Cancer Res (2014) 74:7168-74. doi: 10.1158/0008-5472.CAN-14-2458

12. Nolz JC, Starbeck-Miller GR, Harty JT. Naive, effector and memory CD8 Tcell trafficking: parallels and distinctions. Immunotherapy (2011) 3:1223-33. doi: $10.2217 /$ imt.11.100

13. Fisher DT, Chen Q, Skitzki JJ, Muhitch JB, Zhou L., Appenheimer MM, et al. IL6 trans-signaling licenses mouse and human tumor microvascular gateways for trafficking of cytotoxic T cells. J Clin Invest (2011) 121:3846-59. doi: 10.1172/ JCI44952

14. Zhang F, Yu W, Hargrove JL, Greenspan P, Dean RG, Taylor EW, et al. Inhibition of TNF-alpha induced ICAM-1, VCAM-1 and E-selectin expression by selenium. Atherosclerosis (2002) 161:381-6. doi: 10.1016/S0021-9150(01) 00672-4

15. Groom JR, Luster AD. CXCR3 ligands: redundant, collaborative and antagonistic functions. Immunol Cell Biol (2011) 89:207-15. doi: 10.1038/ icb. 2010.158 
16. Giannopoulos A, Constantinides C, Fokaeas E, Stravodimos C, Giannopoulou M, Kyroudi A., et al. The immunomodulating effect of interferon-gamma intravesical instillations in preventing bladder cancer recurrence. Clin Cancer Res (2003) 9:5550-8.

17. Fisher DT, Appenheimer MM, Evans SS. The two faces of IL-6 in the tumor microenvironment. Semin Immunol (2014) 26:38-47. doi: 10.1016/j.smim. 2014.01.008

18. Steding CE, Wu S-T, Zhang Y, Jeng M-H, Elzey BD, Kao C., et al. The role of interleukin-12 on modulating myeloid-derived suppressor cells, increasing overall survival and reducing metastasis. Immunology (2011) 133:221-38. doi: 10.1111/j.1365-2567.2011.03429.x

19. Dostert C, Grusdat M, Letellier E, Brenner D. The TNF Family of Ligands and Receptors: Communication Modules in the Immune System and Beyond. Physiol Rev (2019) 99:115-60. doi: 10.1152/physrev.00045.2017

20. Harjunpää H, Llort Asens M, Guenther C, Fagerholm SC. Cell Adhesion Molecules and Their Roles and Regulation in the Immune and Tumor Microenvironment. Front Immunol (2019) 10:1078. doi: 10.3389/fimmu. 2019.01078

21. Curnis F, Gasparri A, Sacchi A, Longhi R, Corti A. Coupling Tumor Necrosis Factor- $\alpha$ with $\alpha$ VIntegrin Ligands Improves Its Antineoplastic Activity. Cancer Res (2004) 64:565-71. doi: 10.1158/0008-5472.CAN-031753

22. Metzemaekers M, Vanheule V, Janssens R, Struyf S, Proost P. Overview of the Mechanisms that May Contribute to the Non-Redundant Activities of Interferon-Inducible CXC Chemokine Receptor 3 Ligands. Front Immunol (2017) 8:1970. doi: 10.3389/fimmu.2017.01970

23. Liu Z, Ravindranathan R, Li J, Kalinski P, Guo ZS, Bartlett DL. CXCL11Armed oncolytic poxvirus elicits potent antitumor immunity and shows enhanced therapeutic efficacy. Oncoimmunology (2016) 5:e1091554. doi: 10.1080/2162402X.2015.1091554

24. Arenberg DA, White ES, Burdick MD, Strom SR, Strieter RM. Improved survival in tumor-bearing SCID mice treated with interferon-gammainducible protein 10 (IP-10/CXCL10). Cancer Immunol Immunother (2001) 50:533-8. doi: 10.1007/s00262-001-0231-9

25. Moon EK, Wang L-CS, Bekdache K, Lynn RC, Lo A, Thorne SH, et al. Intratumoral delivery of CXCL11 via a vaccinia virus, but not by modified $\mathrm{T}$ cells, enhances the efficacy of adoptive $\mathrm{T}$ cell therapy and vaccines. OncoImmunology (2018) 7:e1395997. doi: 10.1080/2162402X.2017.1395997

26. Liu Y, Huang H, Saxena A, Xiang J. Intratumoral coinjection of two adenoviral vectors expressing functional interleukin-18 and inducible protein-10, respectively, synergizes to facilitate regression of established tumors. Cancer Gene Ther (2002) 9:533-42. doi: 10.1038/sj.cgt.7700466

27. Matsumura S, Wang B, Kawashima N, Braunstein S, Badura M, Cameron TO, et al. Radiation-induced CXCL16 release by breast cancer cells attracts effector T cells. J Immunol (2008) 181:3099-107. doi: 10.4049/ jimmunol.181.5.3099

28. Hojo S, Koizumi K, Tsuneyama K, Arita Y, Cui Z, Shinohara K, et al. Highlevel expression of chemokine CXCL16 by tumor cells correlates with a good prognosis and increased tumor-infiltrating lymphocytes in colorectal cancer. Cancer Res (2007) 67:4725-31. doi: 10.1158/0008-5472.CAN-06-3424

29. Shulman Z, Cohen SJ, Roediger B, Kalchenko V, Jain R, Grabovsky V, et al. Transendothelial migration of lymphocytes mediated by intraendothelial vesicle stores rather than by extracellular chemokine depots. Nat Immunol (2011) 13:67-76. doi: 10.1038/ni.2173

30. Moon EK, Carpenito C, Sun J, Wang L-CS, Kapoor V, Predina J, et al. Expression of a functional CCR2 receptor enhances tumor localization and tumor eradication by retargeted human $\mathrm{T}$ cells expressing a mesothelinspecific chimeric antibody receptor. Clin Cancer Res (2011) 17:4719-30. doi: 10.1158/1078-0432.CCR-11-0351

31. Craddock JA, Lu A, Bear A, Pule M, Brenner MK, Rooney CM, et al. Enhanced tumor trafficking of GD2 chimeric antigen receptor $\mathrm{T}$ cells by expression of the chemokine receptor CCR2b. J Immunother (2010) 33:7808. doi: 10.1097/CJI.0b013e3181ee6675

32. Spranger S, Dai D, Horton B, Gajewski TF. Tumor-Residing Batf3 Dendritic Cells Are Required for Effector T Cell Trafficking and Adoptive T Cell Therapy. Cancer Cell (2017) 31:711-723.e4. doi: 10.1016/j.ccell.2017.04.003

33. Sweis RF, Spranger S, Bao R, Paner GP, Stadler WM, Steinberg G, et al. Molecular Drivers of the Non-T-cell-Inflamed Tumor Microenvironment in
Urothelial Bladder Cancer. Cancer Immunol Res (2016) 4:563-8. doi: 10.1158/2326-6066.CIR-15-0274

34. Gough M, Crittenden M, Thanarajasingam U, Sanchez-Perez L, Thompson J, Jevremovic $\mathrm{D}$, et al. Gene therapy to manipulate effector $\mathrm{T}$ cell trafficking to tumors for immunotherapy. J Immunol (2005) 174:5766-73. doi: 10.4049/ jimmunol.174.9.5766

35. Moser B, Ebert L. Lymphocyte traffic control by chemokines: follicular B helper T cells. Immunol Lett (2003) 85:105-12. doi: 10.1016/S0165-2478(02) 00233-X

36. Kim J-W, Ferris RL, Whiteside TL. Chemokine C receptor 7 expression and protection of circulating CD8+ T lymphocytes from apoptosis. Clin Cancer Res (2005) 11:7901-10. doi: 10.1158/1078-0432.CCR-05-1346

37. Novak L, Igoucheva O, Cho S, Alexeev V. Characterization of the CCL21mediated melanoma-specific immune responses and in situ melanoma eradication. Mol Cancer Ther (2007) 6:1755-64. doi: 10.1158/1535-7163. MCT-06-0709

38. Kirk CJ, Hartigan-O'Connor D, Nickoloff BJ, Chamberlain JS, Giedlin M, Aukerman $\mathrm{L}$, et al. $\mathrm{T}$ cell-dependent antitumor immunity mediated by secondary lymphoid tissue chemokine: augmentation of dendritic cell-based immunotherapy. Cancer Res (2001) 61:2062-70.

39. Sharma S, Yang S-C, Hillinger S, Zhu LX, Huang M, Batra RK, et al. SLC/ CCL21-mediated anti-tumor responses require IFNgamma, MIG/CXCL9 and IP-10/CXCL10. Mol Cancer (2003) 2:22. doi: 10.1186/1476-4598-2-22

40. Homey B, Alenius H, Müller A, Soto H, Bowman EP, Yuan W, et al. CCL27CCR10 interactions regulate T cell-mediated skin inflammation. Nat Med (2002) 8:157-65. doi: 10.1038/nm0202-157

41. Okada N, Sasaki A, Niwa M, Okada Y, Hatanaka Y, Tani Y, et al. Tumor suppressive efficacy through augmentation of tumor-infiltrating immune cells by intratumoral injection of chemokine-expressing adenoviral vector. Cancer Gene Ther (2006) 13:393-405. doi: 10.1038/sj.cgt.7700903

42. Turnis ME, Sawant DV, Szymczak-Workman AL, Andrews LP, Delgoffe GM, Yano H, et al. Interleukin-35 Limits Anti-Tumor Immunity. Immunity (2016) 44:316-29. doi: 10.1016/j.immuni.2016.01.013

43. Bald T, Smyth MJ. TGF $\beta$ shuts the door on T cells. Br J Cancer (2018) 119:13. doi: $10.1038 / \mathrm{s} 41416-018-0122-\mathrm{x}$

44. Tauriello DVF, Palomo-Ponce S, Stork D, Berenguer-Llergo A, BadiaRamentol J, Iglesias M, et al. TGF $\beta$ drives immune evasion in genetically reconstituted colon cancer metastasis. Nature (2018) 554:538-43. doi 10.1038/nature25492

45. Smith AL, Robin TP, Ford HL. Molecular Pathways: Targeting the TGF- $\beta$ Pathway for Cancer Therapy. Clin Cancer Res (2012) 18:4514-21. doi: 10.1158/1078-0432.CCR-11-3224

46. Kelley RK, Gane E, Assenat E, Siebler J, Galle PR, Merle P, et al. A Phase 2 Study of Galunisertib (TGF- $\beta 1$ Receptor Type I Inhibitor) and Sorafenib in Patients With Advanced Hepatocellular Carcinoma. Clin Transl Gastroenterol (2019) 10:e00056. doi: 10.14309/ctg.0000000000000056

47. Sugasawa H, Ichikura T, Kinoshita M, Ono S, Majima T, Tsujimoto H, et al. Gastric cancer cells exploit CD4 cell-derived CCL5 for their growth and prevention of CD8 cell-involved tumor elimination. Int J Cancer (2008) 122:2535-41. doi: 10.1002/ijc.23401

48. Gulley JL, Heery CR, Schlom J, Madan RA, Cao L, Lamping E, et al. Preliminary results from a phase 1 trial of M7824 (MSB0011359C), a bifunctional fusion protein targeting PD-L1 and TGF- $\beta$, in advanced solid tumors. J Clin Orthod (2017) 35:3006-6. doi: 10.1200/JCO.2017.35. 15_suppl.3006

49. Kloss CC, Lee J, Zhang A, Chen F, Melenhorst JJ, Lacey SF, et al. DominantNegative TGF- $\beta$ Receptor Enhances PSMA-Targeted Human CAR T Cell Proliferation And Augments Prostate Cancer Eradication. Mol Ther (2018) 26:1855-66. doi: 10.1016/j.ymthe.2018.05.003

50. Zhang H, Li Z, Wang L, Tian G, Tian J, Yang Z, et al. Critical Role of Myeloid-Derived Suppressor Cells in Tumor-Induced Liver Immune Suppression through Inhibition of NKT Cell Function. Front Immunol (2017) 8:129. doi: 10.3389/fimmu.2017.00129

51. Hertzer KM, Donald GW, Hines OJ. CXCR2: a target for pancreatic cancer treatment? Expert Opin Ther Targets (2013) 17:667-80. doi: 10.1517/ 14728222.2013.772137

52. Steele CW, Karim SA, Leach JDG, Bailey P, Upstill-Goddard R, Rishi L, et al. CXCR2 Inhibition Profoundly Suppresses Metastases and Augments 
Immunotherapy in Pancreatic Ductal Adenocarcinoma. Cancer Cell (2016) 29:832-45. doi: 10.1016/j.ccell.2016.04.014

53. Alfaro C, Teijeira A, Oñate C, Pérez G, Sanmamed MF, Andueza MP, et al. Tumor-Produced Interleukin-8 Attracts Human Myeloid-Derived Suppressor Cells and Elicits Extrusion of Neutrophil Extracellular Traps (NETs). Clin Cancer Res (2016) 22:3924-36. doi: 10.1158/1078-0432.CCR15-2463

54. Jin L, Tao H, Karachi A, Long Y, Hou AY, Na M, et al. CXCR1- or CXCR2modified CAR T cells co-opt IL-8 for maximal antitumor efficacy in solid tumors. Nat Commun (2019) 10(1):4016. doi: 10.1038/s41467-019-11869-4

55. Poznansky MC, Olszak IT, Foxall R, Evans RH, Luster AD, Scadden DT. Active movement of T cells away from a chemokine. Nat Med (2000) 6:5438. doi: $10.1038 / 75022$

56. Orimo A, Weinberg RA. Heterogeneity of stromal fibroblasts in tumor. Cancer Biol Ther (2007) 6:618-9. doi: 10.4161/cbt.6.4.4255

57. Murdoch C, Muthana M, Coffelt SB, Lewis CE. The role of myeloid cells in the promotion of tumour angiogenesis. Nat Rev Cancer (2008) 8:618-31. doi: $10.1038 / \mathrm{nrc} 2444$

58. Feig C, Jones JO, Kraman M, Wells RJB, Deonarine A, Chan DS, et al. Targeting CXCL12 from FAP-expressing carcinoma-associated fibroblasts synergizes with anti-PD-L1 immunotherapy in pancreatic cancer. Proc Natl Acad Sci USA (2013) 110:20212-7. doi: 10.1073/pnas.1320318110

59. Qian B-Z, Li J, Zhang H, Kitamura T, Zhang J, Campion LR, et al. CCL2 recruits inflammatory monocytes to facilitate breast-tumour metastasis. Nature (2011) 475:222-5. doi: 10.1038/nature10138

60. Huang B, Lei Z, Zhao J, Gong W, Liu J, Chen Z, et al. CCL2/CCR2 pathway mediates recruitment of myeloid suppressor cells to cancers. Cancer Lett (2007) 252:86-92. doi: 10.1016/j.canlet.2006.12.012

61. Mondini M, Loyher P-L, Hamon P, Gerbé de Thoré M, Laviron M, Berthelot K, et al. CCR2-Dependent Recruitment of Tregs and Monocytes Following Radiotherapy Is Associated with TNF $\alpha$-Mediated Resistance. Cancer Immunol Res (2019) 7:376-87. doi: 10.1158/2326-6066.CIR-18-0633

62. Soria G, Yaal-Hahoshen N, Azenshtein E, Shina S, Leider-Trejo L, Ryvo L, et al. Concomitant expression of the chemokines RANTES and MCP-1 in human breast cancer: A basis for tumor-promoting interactions. Cytokine (2008) 44:191-200. doi: 10.1016/j.cyto.2008.08.002

63. Tan MCB, Goedegebuure PS, Belt BA, Flaherty B, Sankpal N, Gillanders WE, et al. Disruption of CCR5-Dependent Homing of Regulatory T Cells Inhibits Tumor Growth in a Murine Model of Pancreatic Cancer. J Immunol (2009) 182:1746-55. doi: 10.4049/jimmunol.182.3.1746

64. Maggio EM, Van Den Berg A, Visser L, Diepstra A, Kluiver J, Emmens R, et al. Common and differential chemokine expression patterns in rs cells of NLP, EBV positive and negative classical Hodgkin lymphomas. Int $J$ Cancer (2002) 99:665-72. doi: 10.1002/ijc.10399

65. van den Berg A, Visser L, Poppema S. High Expression of the CC Chemokine TARC in Reed-Sternberg Cells. Am J Pathol (1999) 154:168591. doi: 10.1016/S0002-9440(10)65424-7

66. Di Stasi A, De Angelis B, Rooney CM, Zhang L, Mahendravada A, Foster AE, et al. T lymphocytes coexpressing CCR4 and a chimeric antigen receptor targeting CD30 have improved homing and antitumor activity in a Hodgkin tumor model. Blood (2009) 113:6392-402. doi: 10.1182/blood-2009-03209650

67. Curiel TJ, Coukos G, Zou L, Alvarez X, Cheng P, Mottram P, et al. Specific recruitment of regulatory $\mathrm{T}$ cells in ovarian carcinoma fosters immune privilege and predicts reduced survival. Nat Med (2004) 10:942-9. doi: $10.1038 / \mathrm{nm} 1093$

68. Facciabene A, Peng X, Hagemann IS, Balint K, Barchetti A, Wang L-P, et al. Tumour hypoxia promotes tolerance and angiogenesis via CCL28 and T (reg) cells. Nature (2011) 475:226-30. doi: 10.1038/nature10169

69. Motz GT, Santoro SP, Wang L-P, Garrabrant T, Lastra RR, Hagemann IS, et al. Tumor endothelium FasL establishes a selective immune barrier promoting tolerance in tumors. Nat Med (2014) 20:607-15. doi: 10.1038/ nm.3541

70. Goel HL, Mercurio AM. VEGF targets the tumour cell. Nat Rev Cancer (2013) 13:871-82. doi: 10.1038/nrc3627

71. Horikawa N, Abiko K, Matsumura N, Hamanishi J, Baba T, Yamaguchi K, et al. Expression of Vascular Endothelial Growth Factor in Ovarian Cancer Inhibits Tumor Immunity through the Accumulation of Myeloid-Derived
Suppressor Cells. Clin Cancer Res (2017) 23:587-99. doi: 10.1158/10780432.CCR-16-0387

72. Meadows KL, Hurwitz HII. Anti-VEGF therapies in the clinic. Cold Spring Harb Perspect Med (2012) 2(10):a006577. doi: 10.1101/cshperspect.a006577

73. Griffioen AW, Damen CA, Blijham GH, Groenewegen G. Tumor angiogenesis is accompanied by a decreased inflammatory response of tumor-associated endothelium. Blood (1996) 88:667-73. doi: 10.1182/ blood.V88.2.667.bloodjournal882667

74. Crawford Y, Kasman I, Yu L, Zhong C, Wu X, Modrusan Z, et al. PDGF-C mediates the angiogenic and tumorigenic properties of fibroblasts associated with tumors refractory to anti-VEGF treatment. Cancer Cell (2009) 15:2134. doi: 10.1016/j.ccr.2008.12.004

75. Rolny C, Mazzone M, Tugues S, Laoui D, Johansson I, Coulon C, et al. HRG inhibits tumor growth and metastasis by inducing macrophage polarization and vessel normalization through downregulation of PlGF. Cancer Cell (2011) 19:31-44. doi: 10.1016/j.ccr.2010.11.009

76. Bellone M, Calcinotto A. Ways to Enhance Lymphocyte Trafficking into Tumors and Fitness of Tumor Infiltrating Lymphocytes. Front Oncol (2013) 3:231. doi: 10.3389/fonc.2013.00231

77. Hodi FS, Lawrence D, Lezcano C, Wu X, Zhou J, Sasada T, et al. Bevacizumab plus ipilimumab in patients with metastatic melanoma. Cancer Immunol Res (2014) 2:632-42. doi: 10.1158/2326-6066.CIR-14-0053

78. Yang J, Yan J, Liu B. Targeting VEGF/VEGFR to Modulate Antitumor Immunity. Front Immunol (2018) 9:978. doi: 10.3389/fimmu.2018.00978

79. Huang Y, Yuan J, Righi E, Kamoun WS, Ancukiewicz M, Nezivar J, et al. Vascular normalizing doses of antiangiogenic treatment reprogram the immunosuppressive tumor microenvironment and enhance immunotherapy. Proc Natl Acad Sci USA (2012) 109:17561-6. doi: 10.1073/pnas.1215397109

80. Jain RK. Normalization of tumor vasculature: an emerging concept in antiangiogenic therapy. Science (2005) 307:58-62. doi: 10.1126/ science. 1104819

81. Bertrand F, Rochotte J, Colacios C, Montfort A, Tilkin-Mariamé A-F, Touriol C, et al. Blocking Tumor Necrosis Factor $\alpha$ Enhances CD8 T-cellDependent Immunity in Experimental Melanoma. Cancer Res (2015) 75:2619-28. doi: 10.1158/0008-5472.CAN-14-2524

82. Martinet L, Garrido I, Filleron T, Le Guellec S, Bellard E, Fournie J-J, et al. Human Solid Tumors Contain High Endothelial Venules: Association with T- and B-Lymphocyte Infiltration and Favorable Prognosis in Breast Cancer. Cancer Res (2011) 71:5678-87. doi: 10.1158/0008-5472.CAN-11-0431

83. Avram G, Sánchez-Sendra B, Martín JM, Terrádez L, Ramos D, Monteagudo C. The density and type of MECA-79-positive high endothelial venules correlate with lymphocytic infiltration and tumour regression in primary cutaneous melanoma. Histopathology (2013) 63:852-61. doi: 10.1111/ his. 12235

84. Harlin H, Meng Y, Peterson AC, Zha Y, Tretiakova M, Slingluff C, et al. Chemokine Expression in Melanoma Metastases Associated with CD8 TCell Recruitment. Cancer Res (2009) 69:3077-85. doi: 10.1158/00085472.CAN-08-2281

85. Andersson A, Yang S-C, Huang M, Zhu L, Kar UK, Batra RK, et al. IL-7 promotes CXCR3 ligand-dependent $\mathrm{T}$ cell antitumor reactivity in lung cancer. J Immunol (2009) 182:6951-8. doi: 10.4049/jimmunol.0803340

86. Mlecnik B, Tosolini M, Charoentong P, Kirilovsky A, Bindea G, Berger A, et al. Biomolecular network reconstruction identifies T-cell homing factors associated with survival in colorectal cancer. Gastroenterology (2010) 138:1429-40. doi: 10.1053/j.gastro.2009.10.057

87. Li K, Zhu Z, Luo J, Fang J, Zhou H, Hu M, et al. Impact of chemokine receptor CXCR3 on tumor-infiltrating lymphocyte recruitment associated with favorable prognosis in advanced gastric cancer. Int J Clin Exp Pathol (2015) 8:14725-32.

88. Mauldin IS, Wages NA, Stowman AM, Wang E, Smolkin ME, Olson WC, et al. Intratumoral interferon-gamma increases chemokine production but fails to increase $\mathrm{T}$ cell infiltration of human melanoma metastases. Cancer Immunol Immunother (2016) 65:1189-99. doi: 10.1007/s00262-016-1881-y

89. Garcia-Diaz A, Shin DS, Moreno BH, Saco J, Escuin-Ordinas H, Rodriguez GA, et al. Interferon Receptor Signaling Pathways Regulating PD-L1 and PDL2 Expression. Cell Rep (2019) 29:3766. doi: 10.1016/j.celrep.2019.11.113

90. Pai C-CS, Huang JT, Lu X, Simons DM, Park C, Chang A, et al. Clonal Deletion of Tumor-Specific T Cells by Interferon- $\gamma$ Confers Therapeutic 
Resistance to Combination Immune Checkpoint Blockade. Immunity (2019) 50:477-92.e8. doi: 10.1016/j.immuni.2019.01.006

91. Vandercappellen J, Van Damme J, Struyf S. The role of CXC chemokines and their receptors in cancer. Cancer Lett (2008) 267:226-44. doi: 10.1016/ j.canlet.2008.04.050

92. Huffman AP, Lin JH, Kim SII, Byrne KT, Vonderheide RH. CCL5 mediates CD40-driven CD4+ T cell tumor infiltration and immunity. JCI Insight (2020) 5(10):e137263. doi: 10.1172/jci.insight.137263

93. Li L, Yang L, Cheng S, Fan Z, Shen Z, Xue W, et al. Lung adenocarcinomaintrinsic GBE1 signaling inhibits anti-tumor immunity. Mol Cancer (2019) 18:108. doi: 10.1186/s12943-019-1027-x

94. Rosenberg SA, Yang JC, White DE, Steinberg SM. Durability of complete responses in patients with metastatic cancer treated with high-dose interleukin-2: identification of the antigens mediating response. Ann Surg (1998) 228:307-19. doi: 10.1097/00000658-199809000-00004

95. Rosenberg SA, Sportès C, Ahmadzadeh M, Fry TJ, Ngo LT, Schwarz SL, et al. IL-7 administration to humans leads to expansion of CD8+ and CD4+ cells but a relative decrease of CD4+ T-regulatory cells. J Immunother (2006) 29:313-9. doi: 10.1097/01.cji.0000210386.55951.c2

96. Conlon KC, Lugli E, Welles HC, Rosenberg SA, Fojo AT, Morris JC, et al. Redistribution, hyperproliferation, activation of natural killer cells and CD8 $\mathrm{T}$ cells, and cytokine production during first-in-human clinical trial of recombinant human interleukin-15 in patients with cancer. J Clin Oncol (2015) 33:74-82. doi: 10.1200/JCO.2014.57.3329

97. Wrangle JM, Velcheti V, Patel MR, Garrett-Mayer E, Hill EG, Ravenel JG, et al. ALT-803, an IL-15 superagonist, in combination with nivolumab in patients with metastatic non-small cell lung cancer: a non-randomised, open-label, phase 1b trial. Lancet Oncol (2018) 19:694-704. doi: 10.1016/ S1470-2045(18)30148-7

98. Zeng R, Spolski R, Finkelstein SE, Oh S, Kovanen PE, Hinrichs CS, et al. Synergy of IL-21 and IL-15 in regulating CD8+ T cell expansion and function. J Exp Med (2005) 201:139-48. doi: 10.1084/jem.20041057

99. Imagawa Y, Satake K, Kato Y, Tahara H, Tsukuda M. Antitumor and antiangiogenic effects of interleukin 12 gene therapy in murine head and neck carcinoma model. Auris Nasus Larynx (2004) 31:239-45. doi: 10.1016/ j.anl.2004.03.008

100. Airoldi I, Di Carlo E, Cocco C, Taverniti G, D’Antuono T, Ognio E, et al. Endogenous IL-12 triggers an antiangiogenic program in melanoma cells. Proc Natl Acad Sci USA (2007) 104:3996-4001. doi: 10.1073/pnas.0609028104

101. Petersen CT, Krenciute G. Next Generation CAR T Cells for the Immunotherapy of High-Grade Glioma. Front Oncol (2019) 9:69. doi: 10.3389/fonc.2019.00069

102. Chmielewski M, Abken H. TRUCKs: the fourth generation of CARs. Expert Opin Biol Ther (2015) 15:1145-54. doi: 10.1517/14712598.2015.1046430

103. Adachi K, Kano Y, Nagai T, Okuyama N, Sakoda Y, Tamada K. IL-7 and CCL19 expression in CAR-T cells improves immune cell infiltration and CAR-T cell survival in the tumor. Nat Biotechnol (2018) 36:346-51. doi: $10.1038 /$ nbt.4086

104. Shum T, Omer B, Tashiro H, Kruse RL, Wagner DL, Parikh K, et al. Constitutive Signaling from an Engineered IL7 Receptor Promotes Durable Tumor Elimination by Tumor-Redirected T Cells. Cancer Discovery (2017) 7:1238-47. doi: 10.1158/2159-8290.CD-17-0538

105. Kagoya Y, Tanaka S, Guo T, Anczurowski M, Wang C-H, Saso K, et al. A novel chimeric antigen receptor containing a JAK-STAT signaling domain mediates superior antitumor effects. Nat Med (2018) 24:352-9. doi: 10.1038/nm.4478

106. Bajgain P, Tawinwung S, D'Elia L, Sukumaran S, Watanabe N, Hoyos V, et al. CAR $T$ cell therapy for breast cancer: harnessing the tumor milieu to drive $\mathrm{T}$ cell activation. J Immunother Cancer (2018) 6:34. doi: 10.1186/s40425-018-0347-5

107. Sockolosky JT, Trotta E, Parisi G, Picton L, Su LL, Le AC, et al. Selective targeting of engineered T cells using orthogonal IL-2 cytokine-receptor complexes. Science (2018) 359:1037-42. doi: 10.1126/science.aar3246

108. Ansell SM, Northfelt DW, Flinn I, Burris HA, Dinner SN, Villalobos VM, et al. Phase I evaluation of an agonist anti-CD27 human antibody (CDX1127) in patients with advanced hematologic malignancies. J Clin Oncol (2014) 32:3024-4. doi: 10.1200/jco.2014.32.15_suppl.3024

109. Kleber S, Sancho-Martinez I, Wiestler B, Beisel A, Gieffers C, Hill O, et al. Yes and PI3K bind CD95 to signal invasion of glioblastoma. Cancer Cell (2008) 13:235-48. doi: 10.1016/j.ccr.2008.02.003
110. Huang H, Langenkamp E, Georganaki M, Loskog A, Fuchs PF, Dieterich LC, et al. VEGF suppresses T-lymphocyte infiltration in the tumor microenvironment through inhibition of NF- $\mathrm{KB}$-induced endothelial activation. FASEB J (2015) 29:227-38. doi: 10.1096/fj.14-250985

111. Pylayeva-Gupta Y, Das S, Handler JS, Hajdu CH, Coffre M, Koralov SB, et al. IL35-Producing B Cells Promote the Development of Pancreatic Neoplasia. Cancer Discovery (2016) 6:247-55. doi: 10.1158/2159-8290.CD-15-0843

112. Mariathasan S, Turley SJ, Nickles D, Castiglioni A, Yuen K, Wang Y, et al. TGFB attenuates tumour response to PD-L1 blockade by contributing to exclusion of T cells. Nature (2018) 554:544-8. doi: 10.1038/nature25501

113. Knudson KM, Hicks KC, Luo X, Chen J-Q, Schlom J, Gameiro SR. M7824, a novel bifunctional anti-PD-L1/TGF $\beta$ Trap fusion protein, promotes antitumor efficacy as monotherapy and in combination with vaccine. Oncoimmunology (2018) 7:e1426519. doi: 10.1080/2162402X.2018.1426519

114. Cheng LE, Ohlén C, Nelson BH, Greenberg PD. Enhanced signaling through the IL-2 receptor in $\mathrm{CD} 8+\mathrm{T}$ cells regulated by antigen recognition results in preferential proliferation and expansion of responding CD8+ T cells rather than promotion of cell death. Proc Natl Acad Sci USA (2002) 99:3001-6. doi: 10.1073/pnas.052676899

115. D'Souza WN, Lefrançois L. IL-2 is not required for the initiation of CD8 T cell cycling but sustains expansion. J Immunol (2003) 171:5727-35. doi: 10.4049/jimmunol.171.11.5727

116. Malek TR. The biology of interleukin-2. Annu Rev Immunol (2008) 26:45379. doi: 10.1146/annurev.immunol.26.021607.090357

117. Rosenberg SA. IL-2: The First Effective Immunotherapy for Human Cancer. J Immunol (2014) 192:5451-8. doi: 10.4049/jimmunol.1490019

118. Jiang Q, Li WQ, Hofmeister RR, Young HA, Hodge DR, Keller JR, et al. Distinct regions of the interleukin-7 receptor regulate different Bcl2 family members. Mol Cell Biol (2004) 24:6501-13. doi: 10.1128/MCB.24.14.6501-6513.2004

119. Akashi K, Kondo M, von Freeden-Jeffry U, Murray R, Weissman IL. Bcl-2 Rescues T Lymphopoiesis in Interleukin-7 Receptor-Deficient Mice. Cell (1997) 89:1033-41. doi: 10.1016/S0092-8674(00)80291-3

120. Carrio R, Rolle CE, Malek TR. Non-redundant role for IL-7R signaling for the survival of CD8+ memory T cells. Eur J Immunol (2007) 37:3078-88. doi: 10.1002/eji.200737585

121. Sportès C, Hakim FT, Memon SA, Zhang H, Chua KS, Brown MR, et al. Administration of rhIL-7 in humans increases in vivo TCR repertoire diversity by preferential expansion of naive T cell subsets. $J$ Exp Med (2008) 205:1701-14. doi: 10.1084/jem.20071681

122. Moore KW, de Waal Malefyt R, Coffman RL, O'Garra A. Interleukin-10 and the interleukin-10 receptor. Annu Rev Immunol (2001) 19:683-765. doi: 10.1146/annurev.immunol.19.1.683

123. Emmerich J, Mumm JB, Chan IH, LaFace D, Truong H, McClanahan T, et al. IL-10 directly activates and expands tumor-resident CD8(+) T cells without de novo infiltration from secondary lymphoid organs. Cancer Res (2012) 72:3570-81. doi: 10.1158/0008-5472.CAN-12-0721

124. Mumm JB, Emmerich J, Zhang X, Chan I, Wu L, Mauze S, et al. IL-10 elicits IFN $\gamma$-dependent tumor immune surveillance. Cancer Cell (2011) 20:781-96. doi: 10.1016/j.ccr.2011.11.003

125. Watford WT, Moriguchi M, Morinobu A, O'Shea JJ. The biology of IL-12: coordinating innate and adaptive immune responses. Cytokine Growth Factor Rev (2003) 14:361-8. doi: 10.1016/S1359-6101(03)00043-1

126. Strauss J, Heery CR, Kim JW, Jochems C, Donahue RN, Montgomery AS, et al. First-in-Human Phase I Trial of a Tumor-Targeted Cytokine (NHSIL12) in Subjects with Metastatic Solid Tumors. Clin Cancer Res (2019) 25:99-109. doi: 10.1158/1078-0432.CCR-18-1512

127. Steel JC, Waldmann TA, Morris JC. Interleukin-15 biology and its therapeutic implications in cancer. Trends Pharmacol Sci (2012) 33:35-41. doi: 10.1016/j.tips.2011.09.004

128. Gargett T, Brown MP. Different cytokine and stimulation conditions influence the expansion and immune phenotype of third-generation chimeric antigen receptor T cells specific for tumor antigen GD2. Cytotherapy (2015) 17:487-95. doi: 10.1016/j.jcyt.2014.12.002

129. Freeman BE, Hammarlund E, Raué H-P, Slifka MK. Regulation of innate CD8+ T-cell activation mediated by cytokines. Proc Natl Acad Sci USA (2012) 109:9971-6. doi: 10.1073/pnas.1203543109

130. Soudja SM, Ruiz AL, Marie JC, Lauvau G. Inflammatory Monocytes Activate Memory CD8 T and Innate NK Lymphocytes Independent of Cognate 
Antigen during Microbial Pathogen Invasion. Immunity (2012) 37:549-62. doi: 10.1016/j.immuni.2012.05.029

131. Xu D, Trajkovic V, Hunter D, Leung BP, Schulz K, Gracie JA, et al. IL-18 induces the differentiation of Th1 or Th2 cells depending upon cytokine milieu and genetic background. Eur J Immunol (2000) 30:3147-56. doi: 10.1002/1521-4141(200011)30:11<3147::AID-IMMU3147>3.0.CO;2-J

132. Li Y, Yee C. IL-21 mediated Foxp3 suppression leads to enhanced generation of antigen-specific CD8+ cytotoxic T lymphocytes. Blood (2008) 111:229-35. doi: 10.1182/blood-2007-05-089375

133. Liu S, Lizée G, Lou Y, Liu C, Overwijk WW, Wang G, et al. IL-21 synergizes with IL-7 to augment expansion and anti-tumor function of cytotoxic T cells. Int Immunol (2007) 19:1213-21. doi: 10.1093/intimm/dxm093

134. Hendriks J, Gravestein LA, Tesselaar K, van Lier RA, Schumacher TN, Borst J. $\mathrm{CD} 27$ is required for generation and long-term maintenance of $\mathrm{T}$ cell immunity. Nat Immunol (2000) 1:433-40. doi: 10.1038/80877

135. Thiemann M, Richards DM, Heinonen K, Kluge M, Marschall V, Merz C, et al. A Single-Chain-Based Hexavalent CD27 Agonist Enhances T Cell Activation and Induces Anti-Tumor Immunity. Front Oncol (2018) 8:387. doi: $10.3389 /$ fonc. 2018.00387

136. Sanborn RE, Pishvaian MJ, Callahan MK, Weise AM, Sikic BI, Rahma OE, et al. Anti-CD27 agonist antibody varlilumab (varli) with nivolumab (nivo) for colorectal (CRC) and ovarian (OVA) cancer: Phase (Ph) 1/2 clinical trial results. JClin Oncol (2018) 36:3001-1. doi: 10.1200/JCO.2018.36.15_suppl.3001

137. Croft M. The role of TNF superfamily members in T-cell function and diseases. Nat Rev Immunol (2009) 9:271-85. doi: 10.1038/nri2526

138. Zhao Z, Condomines M, van der Stegen SJC, Perna F, Kloss CC, Gunset G, et al. Structural Design of Engineered Costimulation Determines Tumor Rejection Kinetics and Persistence of CAR T Cells. Cancer Cell (2015) 28:415-28. doi: 10.1016/j.ccell.2015.09.004

139. Link A, Vogt TK, Favre S, Britschgi MR, Acha-Orbea H, Hinz B, et al. Fibroblastic reticular cells in lymph nodes regulate the homeostasis of naive T cells. Nat Immunol (2007) 8:1255-65. doi: 10.1038/ni1513

140. Luther SA, Bidgol A, Hargreaves DC, Schmidt A, Xu Y, Paniyadi J, et al. Differing activities of homeostatic chemokines CCL19, CCL21, and CXCL12 in lymphocyte and dendritic cell recruitment and lymphoid neogenesis. J Immunol (2002) 169:424-33. doi: 10.4049/jimmunol.169.1.424

141. Flanagan K, Moroziewicz D, Kwak H, Hörig H, Kaufman HL. The lymphoid chemokine CCL21 costimulates naive $\mathrm{T}$ cell expansion and Th1 polarization of non-regulatory CD4+ T cells. Cell Immunol (2004) 231:75-84. doi: 10.1016/j.cellimm.2004.12.006

142. Thanarajasingam U, Sanz L, Diaz R, Qiao J, Sanchez-Perez L, Kottke T, et al. Delivery of CCL21 to metastatic disease improves the efficacy of adoptive T-cell therapy. Cancer Res (2007) 67:300-8. doi: 10.1158/0008-5472.CAN-06-1017

143. Rosenberg SA, Yang JC, Sherry RM, Kammula US, Hughes MS, Phan GQ, et al. Durable complete responses in heavily pretreated patients with metastatic melanoma using T-cell transfer immunotherapy. Clin Cancer Res (2011) 17:4550-7. doi: 10.1158/1078-0432.CCR-11-0116

144. Chavez ARV, de Vivar Chavez AR, Buchser W, Basse PH, Liang X, Appleman LJ, et al. Pharmacologic Administration of Interleukin-2. Ann New York Acad Sci (2009) 1182:14-27. doi: 10.1111/j.1749-6632.2009.05160.x

145. Panelli MC, White R, Foster M, Martin B, Wang E, Smith K, et al. Forecasting the cytokine storm following systemic interleukin (IL)-2 administration. J Transl Med (2004) 2:17. doi: 10.1186/1479-5876-2-17

146. Sim GC, Martin-Orozco N, Jin L, Yang Y, Wu S, Washington E, et al. IL-2 therapy promotes suppressive ICOS+ Treg expansion in melanoma patients. J Clin Invest (2014) 124:99-110. doi: 10.1172/JCI46266

147. Levin AM, Bates DL, Ring AM, Krieg C, Lin JT, Su L, et al. Exploiting a natural conformational switch to engineer an interleukin-2 "superkine." Nature (2012) 484:529-33. doi: 10.1038/nature10975

148. Létourneau S, van Leeuwen EMM, Krieg C, Martin C, Pantaleo G, Sprent J, et al. IL-2/anti-IL-2 antibody complexes show strong biological activity by avoiding interaction with IL-2 receptor alpha subunit CD25. Proc Natl Acad Sci USA (2010) 107:2171-6. doi: 10.1073/pnas.0909384107

149. Boyman O, Kovar M, Rubinstein MP, Surh CD, Sprent J. Selective stimulation of $\mathrm{T}$ cell subsets with antibody-cytokine immune complexes. Science (2006) 311:1924-7. doi: 10.1126/science.1122927

150. Dwyer CJ, Knochelmann HM, Smith AS, Wyatt MM, Rangel Rivera GO, Arhontoulis DC, et al. Fueling Cancer Immunotherapy With Common
Gamma Chain Cytokines. Front Immunol (2019) 10:263. doi: 10.3389/ fimmu.2019.00263

151. Soudja SM, Ruiz AL, Marie JC, Lauvau G. Inflammatory monocytes activate memory CD8(+) T and innate NK lymphocytes independent of cognate antigen during microbial pathogen invasion. Immunity (2012) 37(3):549-62. doi: 10.1016/j.immuni.2012.05.029

152. Dummy. From CARs to TRUCKs and Beyond: Safely en Route to Adoptive T-cell Therapy for Cancer. EBioMedicine (2016) 14:1-2. doi: 10.1016/ j.ebiom.2016.11.037

153. Maude SL, Frey N, Shaw PA, Aplenc R, Barrett DM. Chimeric antigen receptor T cells for sustained remissions in leukemia. N Engl J Med (2014) 371:1507-17.

154. Borst J, Hendriks J, Xiao Y. CD27 and CD70 in T cell and B cell activation. Curr Opin Immunol (2005) 17:275-81. doi: 10.1016/j.coi.2005.04.004

155. Abolhassani H, Edwards ESJ, Ikinciogullari A, Jing H, Borte S, Buggert M, et al. Combined immunodeficiency and Epstein-Barr virus-induced B cell malignancy in humans with inherited CD70 deficiency. J Exp Med (2017) 214:91-106. doi: 10.1084/jem.20160849

156. Watts TH. TNF/TNFR family members in costimulation of $\mathrm{T}$ cell responses. Annu Rev Immunol (2005) 23:23-68. doi: 10.1146/annurev.immunol. 23.021704.115839

157. Melero I, Hervas-Stubbs S, Glennie M, Pardoll DM, Chen L. Immunostimulatory monoclonal antibodies for cancer therapy. Nat Rev Cancer (2007) 7:95-106. doi: 10.1038/nrc2051

158. Segal NH, Logan TF, Hodi FS, McDermott D, Melero I, Hamid O, et al. Results from an Integrated Safety Analysis of Urelumab, an Agonist AntiCD137 Monoclonal Antibody. Clin Cancer Res (2017) 23:1929-36. doi: 10.1158/1078-0432.CCR-16-1272

159. Kochenderfer JN, Dudley ME, Feldman SA, Wilson WH, Spaner DE, Maric I, et al. B-cell depletion and remissions of malignancy along with cytokine-associated toxicity in a clinical trial of anti-CD19 chimeric-antigen-receptor-transduced T cells. Blood (2012) 119:2709-20. doi: 10.1182/blood-2011-10-384388

160. Kalos M, Levine BL, Porter DL, Katz S, Grupp SA, Bagg A, et al. T cells with chimeric antigen receptors have potent antitumor effects and can establish memory in patients with advanced leukemia. Sci Transl Med (2011) 3:95ra73. doi: $10.1126 /$ scitranslmed.3002842

161. Gao J, Zhao L, Wan YY, Zhu B. Mechanism of Action of IL-7 and Its Potential Applications and Limitations in Cancer Immunotherapy. Int J Mol Sci (2015) 16:10267-80. doi: 10.3390/ijms160510267

162. Damo M, Joshi NS. Treg cell IL-10 and IL-35 exhaust CD8 T cells in tumors. Nat Immunol (2019) 20:674-5. doi: 10.1038/s41590-019-0389-y

163. Smith LK, Boukhaled GM, Condotta SA, Mazouz S, Guthmiller JJ, Vijay R, et al. Interleukin-10 Directly Inhibits CD8 T Cell Function by Enhancing NGlycan Branching to Decrease Antigen Sensitivity. Immunity (2018) 48:299312.e5. doi: 10.1016/j.immuni.2018.01.006

164. Herbein G, Mahlknecht U, Batliwalla F, Gregersen P, Pappas T, Butler J, et al. Apoptosis of CD8+ T cells is mediated by macrophages through interaction of HIV gp120 with chemokine receptor CXCR4. Nature (1998) 395:189-94. doi: $10.1038 / 26026$

165. Bertrand F, Montfort A, Marcheteau E, Imbert C, Gilhodes J, Filleron T, et al. $\mathrm{TNF} \alpha$ blockade overcomes resistance to anti-PD-1 in experimental melanoma. Nat Commun (2017) 8:2256. doi: 10.1038/s41467-017-02358-7

166. Strasser A, Jost PJ, Nagata S. The many roles of FAS receptor signaling in the immune system. Immunity (2009) 30:180-92. doi: 10.1016/j.immuni.2009.01.001

167. Yamamoto TN, Lee P-H, Vodnala SK, Gurusamy D, Kishton RJ, Yu Z, et al. $\mathrm{T}$ cells genetically engineered to overcome death signaling enhance adoptive cancer immunotherapy. J Clin Invest (2019) 129:1551-65. doi: 10.1172/ JCI121491

168. Chyuan I-T, Tsai H-F, Wu C-S, Sung C-C, Hsu P-N. TRAIL-Mediated Suppression of T Cell Receptor Signaling Inhibits T Cell Activation and Inflammation in Experimental Autoimmune Encephalomyelitis. Front Immunol (2018) 9:15. doi: 10.3389/fimmu.2018.00015

169. Tschumi BO, Dumauthioz N, Marti B, Zhang L, Lanitis E, Irving M, et al. CART cells are prone to Fas- and DR5-mediated cell death. J Immunother Cancer (2018) 6:71. doi: 10.1186/s40425-018-0385-z

170. Tschumi BO, Dumauthioz N, Marti B, Zhang L, Lanitis E, Irving M, et al. Correction to: CART cells are prone to Fas- and DR5-mediated cell death. J Immunother Cancer (2018) 6:92. doi: 10.1186/s40425-018-0410-2 
171. McKarns SC, Schwartz RH. Distinct Effects of TGF- $\beta 1$ on CD4 and CD8 T Cell Survival, Division, and IL-2 Production: A Role for T Cell Intrinsic Smad3. J Immunol (2005) 174:2071-83. doi: 10.4049/jimmunol.174.4.2071

172. Brabletz T, Pfeuffer I, Schorr E, Siebelt F, Wirth T, Serfling E, et al Transforming growth factor beta and cyclosporin A inhibit the inducible activity of the interleukin-2 gene in T cells through a noncanonical octamerbinding site. Mol Cell Biol (1993) 13:1155-62. doi: 10.1128/MCB.13.2.1155

173. Kehrl JH, Wakefield LM, Roberts AB, Jakowlew S, Alvarez-Mon M, Derynck R, et al. Production of transforming growth factor beta by human $\mathrm{T}$ lymphocytes and its potential role in the regulation of T cell growth. J Exp Med (1986) 163:1037-50. doi: 10.1084/jem.163.5.1037

174. Mellado M, de Ana AM, Moreno MC, Martínez C, Rodríguez-Frade JM. A potential immune escape mechanism by melanoma cells through the activation of chemokine-induced T cell death. Curr Biol (2001) 11:691-6. doi: 10.1016/S0960-9822(01)00199-3

175. Chang L-Y, Lin Y-C, Mahalingam J, Huang C-T, Chen T-W, Kang C-W, et al. Tumor-Derived Chemokine CCL5 Enhances TGF- -Mediated Killing of CD8 T Cells in Colon Cancer by T-Regulatory Cells. Cancer Res (2012) 72:1092-102. doi: 10.1158/0008-5472.CAN-11-2493

176. Alderson MR, Tough TW, Davis-Smith T, Braddy S, Falk B, Schooley KA, et al. Fas ligand mediates activation-induced cell death in human $\mathrm{T}$ lymphocytes. J Exp Med (1995) 181:71-7. doi: 10.1084/jem.181.1.71

177. Zhu J, Petit P-F, Van den Eynde BJ. Apoptosis of tumor-infiltrating T lymphocytes: a new immune checkpoint mechanism. Cancer Immunol Immunother (2019) 68:835-47. doi: 10.1007/s00262-018-2269-y

178. Lee W-H, Seo D, Lim S-G, Suk K. Reverse Signaling of Tumor Necrosis Factor Superfamily Proteins in Macrophages and Microglia: Superfamily Portrait in the Neuroimmune Interface. Front Immunol (2019) 10:262. doi: 10.3389/fimmu.2019.00262

179. Choi C, Park JY, Lee J, Lim JH, Shin EC, Ahn YS, et al. Fas ligand and Fas are expressed constitutively in human astrocytes and the expression increases with IL-1, IL-6, TNF-alpha, or IFN-gamma. J Immunol (1999) 162:1889-95.

180. Tischner D, Woess C, Ottina E, Villunger A. Bcl-2-regulated cell death signalling in the prevention of autoimmunity. Cell Death Dis (2010) 1:e48. doi: 10.1038 /cddis.2010.27

181. Wendling U, Walczak H, Dörr J, Jaboci C, Weller M, Krammer PH, et al. Expression of TRAIL receptors in human autoreactive and foreign antigenspecific T cells. Cell Death Differ (2000) 7:637-44. doi: 10.1038/sj.cdd.4400692

182. Zheng L, Fisher G, Miller RE, Peschon J, Lynch DH, Lenardo MJ. Induction of apoptosis in mature T cells by tumour necrosis factor. Nature (1995) 377:348-51. doi: 10.1038/377348a0

183. Vanamee ES, Faustman DL. TNFR2: A Novel Target for Cancer Immunotherapy. Trends Mol Med (2017) 23:1037-46. doi: 10.1016/j.molmed.2017.09.007

184. Weissman IL. Stem cells: units of development, units of regeneration, and units in evolution. Cell (2000) 100:157-68. doi: 10.1016/S0092-8674(00)81692-X

185. Youngblood B, Hale JS, Kissick HT, Ahn E, Xu X, Wieland A, et al. Effector CD8 T cells dedifferentiate into long-lived memory cells. Nature (2017) 552:404-9. doi: 10.1038/nature25144

186. Pace L, Goudot C, Zueva E, Gueguen P, Burgdorf N, Waterfall JJ, et al. The epigenetic control of stemness in CD8 T cell fate commitment. Science (2018) 359:177-86. doi: 10.1126/science.aah6499

187. Gattinoni L, Lugli E, Ji Y, Pos Z, Paulos CM, Quigley MF, et al. A human memory T cell subset with stem cell-like properties. Nat Med (2011) 17:1290-7. doi: $10.1038 / \mathrm{nm} .2446$

188. Fraietta JA, Nobles CL, Sammons MA, Lundh S, Carty SA, Reich TJ, et al. Disruption of TET2 promotes the therapeutic efficacy of CD19-targeted T cells. Nature (2018) 558:307-12. doi: 10.1038/s41586-018-0178-Z

189. Okita K, Yamakawa T, Matsumura Y, Sato Y, Amano N, Watanabe A, et al. An efficient nonviral method to generate integration-free human-induced pluripotent stem cells from cord blood and peripheral blood cells. Stem Cells (2013) 31:458-66. doi: 10.1002/stem.1293

190. Agarwal P, Raghavan A, Nandiwada SL, Curtsinger JM, Bohjanen PR, Mueller DL, et al. Gene regulation and chromatin remodeling by IL-12 and type I IFN in programming for CD8 T cell effector function and memory. J Immunol (2009) 183:1695-704. doi: 10.4049/jimmunol.0900592

191. Xiao Z, Casey KA, Jameson SC, Curtsinger JM, Mescher MF. Programming for CD8 T cell memory development requires IL-12 or type I IFN. J Immunol (2009) 182:2786-94. doi: 10.4049/jimmunol.0803484
192. Igarashi O, Yamane H, Imajoh-Ohmi S, Nariuchi H. IL-12 receptor (IL-12R) expression and accumulation of IL-12R beta 1 and IL-12R beta 2 mRNAs in CD4+ T cells by costimulation with B7-2 molecules. J Immunol (1998) 160:1638-46

193. Kieper WC, Tan JT, Bondi-Boyd B, Gapin L, Sprent J, Ceredig R, et al. Overexpression of interleukin (IL)-7 leads to IL-15-independent generation of memory phenotype CD8+ T cells. J Exp Med (2002) 195:1533-9. doi: 10.1084/jem.20020067

194. Singh H, Figliola MJ, Dawson MJ, Huls H, Olivares S, Switzer K, et al. Reprogramming CD19-specific T cells with IL-21 signaling can improve adoptive immunotherapy of B-lineage malignancies. Cancer Res (2011) 71:3516-27. doi: 10.1158/0008-5472.CAN-10-3843

195. Bourgeois C, Rocha B, Tanchot C. A role for CD40 expression on CD8+ T cells in the generation of CD8+ T cell memory. Science (2002) 297:2060-3. doi: $10.1126 /$ science. 1072615

196. Weaver CT, Harrington LE, Mangan PR, Gavrieli M, Murphy KM. Th17: an effector CD4 T cell lineage with regulatory T cell ties. Immunity (2006) 24:677-88. doi: 10.1016/j.immuni.2006.06.002

197. Lee YK, Turner H, Maynard CL, Oliver JR, Chen D, Elson CO, et al. Late developmental plasticity in the T helper 17 lineage. Immunity (2009) 30:92107. doi: 10.1016/j.immuni.2008.11.005

198. Muranski P, Boni A, Antony PA, Cassard L, Irvine KR, Kaiser A, et al. Tumor-specific Th17-polarized cells eradicate large established melanoma. Blood (2008) 112:362-73. doi: 10.1182/blood-2007-11-120998

199. Pipkin ME, Sacks JA, Cruz-Guilloty F, Lichtenheld MG, Bevan MJ, Rao A. Interleukin-2 and inflammation induce distinct transcriptional programs that promote the differentiation of effector cytolytic T cells. Immunity (2010) 32:79-90. doi: 10.1016/j.immuni.2009.11.012

200. Cieri N, Camisa B, Cocchiarella F, Forcato M, Oliveira G, Provasi E, et al. IL-7 and IL-15 instruct the generation of human memory stem T cells from naive precursors. Blood (2013) 121:573-84. doi: 10.1182/blood-2012-05-431718

201. Ouyang W, Beckett O, Flavell RA, Li MO. An Essential Role of the ForkheadBox Transcription Factor Foxol in Control of T Cell Homeostasis and Tolerance. Immunity (2009) 30:358-71. doi: 10.1016/j.immuni.2009.02.003

202. Wu S, Zhu W, Peng Y, Wang L, Hong Y, Huang L, et al. The Antitumor Effects of Vaccine-Activated CD8 T Cells Associate with Weak TCR Signaling and Induction of Stem-Like Memory T Cells. Cancer Immunol Res (2017) 5:908-19. doi: 10.1158/2326-6066.CIR-17-0016

203. Xu Y, Zhang M, Ramos CA, Durett A, Liu E, Dakhova O, et al. Closely related T-memory stem cells correlate with in vivo expansion of CAR.CD19$\mathrm{T}$ cells and are preserved by IL-7 and IL-15. Blood (2014) 123:3750-9. doi: 10.1182/blood-2014-01-552174

204. Dubois S, Mariner J, Waldmann TA, Tagaya Y. IL-15Ralpha recycles and presents IL-15 In trans to neighboring cells. Immunity (2002) 17:537-47. doi: 10.1016/S1074-7613(02)00429-6

205. Xu W, Jones M, Liu B, Zhu X, Johnson CB, Edwards AC, et al. Efficacy and mechanism-of-action of a novel superagonist interleukin-15: interleukin-15 receptor $\alpha \mathrm{Su} / \mathrm{Fc}$ fusion complex in syngeneic murine models of multiple myeloma. Cancer Res (2013) 73:3075-86. doi: 10.1158/0008-5472.CAN-122357

206. Hinrichs CS, Spolski R, Paulos CM, Gattinoni L, Kerstann KW, Palmer DC, et al. IL-2 and IL-21 confer opposing differentiation programs to CD8+ T cells for adoptive immunotherapy. Blood (2008) 111:5326-33. doi: 10.1182/ blood-2007-09-113050

207. Markley JC, Sadelain M. IL-7 and IL-21 are superior to IL-2 and IL-15 in promoting human $\mathrm{T}$ cell-mediated rejection of systemic lymphoma in immunodeficient mice. Blood (2010) 115:3508-19. doi: 10.1182/blood2009-09-241398

208. Filatenkov AA, Jacovetty EL, Fischer UB, Curtsinger JM, Mescher MF, Ingulli E. CD4 T Cell-Dependent Conditioning of Dendritic Cells to Produce IL-12 Results in CD8-Mediated Graft Rejection and Avoidance of Tolerance. $J$ Immunol (2005) 174:6909-17. doi: 10.4049/jimmunol.174.11.6909

209. Hombach A, Köhler H, Rappl G, Abken H. Human CD4+ T cells lyse target cells via granzyme/perforin upon circumvention of MHC class II restriction by an antibody-like immunoreceptor. J Immunol (2006) 177:5668-75.

210. Oh DY, Kwek SS, Raju SS, Li T, McCarthy E, Chow E, et al. Intratumoral CD4 T Cells Mediate Anti-tumor Cytotoxicity in Human Bladder Cancer. Cell (2020) 181:1612-25.e13. 
211. Takeuchi A, Saito T. CD4 CTL, a Cytotoxic Subset of CD4 T Cells, Their Differentiation and Function. Front Immunol (2017) 8:194.

212. Appay V, Zaunders JJ, Papagno L, Sutton J, Jaramillo A, Waters A, et al. Characterization of CD4(+) CTLs ex vivo. J Immunol (2002) 168:5954-8.

213. Nishimura T, Iwakabe K, Sekimoto M, Ohmi Y, Yahata T, Nakui M, et al. Distinct Role of Antigen-Specific T Helper Type 1 (Th1) and Th2 Cells in Tumor Eradication in Vivo. J Exp Med (1999) 190:617-28. doi: 10.1084/ jem.190.5.617

214. Hung K, Hayashi R, Lafond-Walker A, Lowenstein C, Pardoll D, Levitsky H, et al. The Central Role of CD4 T Cells in the Antitumor Immune Response. J Exp Med (1998) 188:2357-68. doi: 10.1084/jem.188.12.2357

215. Jenner RG, Townsend MJ, Jackson I, Sun K, Bouwman RD, Young RA, et al. The transcription factors T-bet and GATA-3 control alternative pathways of T-cell differentiation through a shared set of target genes. Proc Natl Acad Sci USA (2009) 106:17876-81. doi: 10.1073/pnas.0909357106

216. Palucka K, Banchereau J. Cancer Immunotherapy via Dendritic Cells. Nat Rev Cancer (2012) 12(4):265-77. doi: 10.1038/nrc3258

217. Nelms K, Keegan AD, Zamorano J, Ryan JJ, Paul WE. The IL-4 receptor: signaling mechanisms and biologic functions. Annu Rev Immunol (1999) 17:701-38. doi: 10.1146/annurev.immunol.17.1.701

218. Maimela NR, Liu S, Zhang Y. Fates of CD8 T cells in Tumor Microenvironment. Comput Struct Biotechnol J (2019) 17:1-13. doi: 10.1016/j.csbj.2018.11.004

219. Yang W-C, Hwang Y-S, Chen Y-Y, Liu C-L, Shen C-N, Hong W-H, et al. Interleukin-4 Supports the Suppressive Immune Responses Elicited by Regulatory T Cells. Front Immunol (2017) 8:1508. doi: 10.3389/ fimmu.2017.01508

220. Tepper RII, Pattengale PK, Leder P. An eosinophil-dependent mechanism for the antitumor effect of interleukin-4. Science (1992) 257(5069):548-51. doi: 10.1126/science.1636093

221. Mattes J, Hulett M, Xie W, Hogan S, Rothenberg ME, Foster P, et al. Immunotherapy of cytotoxic $\mathrm{T}$ cell-resistant tumors by $\mathrm{T}$ helper 2 cells: an eotaxin and STAT6-dependent process. J Exp Med (2003) 197(3):387-93. doi: $10.1084 /$ jem. 20021683

222. Predina J, Eruslanov E, Judy B, Kapoor V, Cheng G, Wang L-C, et al. Changes in the local tumor microenvironment in recurrent cancers may explain the failure of vaccines after surgery. Proc Natl Acad Sci USA (2013) 110:E415-24. doi: 10.1073/pnas.1211850110

223. Gocher AM, Handu S, Workman CJ, Vignali DAA. Interferon gamma production by regulatory $\mathrm{T}$ cells is required for response to cancer immunotherapy. J Immunol (2020) 204:244.8-8.

224. Asadzadeh Z, Mohammadi H, Safarzadeh E, Hemmatzadeh M, MahdianShakib A, Jadidi-Niaragh F, et al. The paradox of Th17 cell functions in tumor immunity. Cell Immunol (2017) 322:15-25. doi: 10.1016/j.cellimm.2017.10.015

225. Muranski P, Borman ZA, Kerkar SP, Klebanoff CA, Ji Y, Sanchez-Perez L, et al. Th17 cells are long lived and retain a stem cell-like molecular signature. Immunity (2011) 35:972-85. doi: 10.1016/j.immuni.2011.09.019

226. Bowers JS, Nelson MH, Majchrzak K, Bailey SR, Rohrer B, Kaiser AD, et al. Th17 cells are refractory to senescence and retain robust antitumor activity after long-term ex vivo expansion. JCI Insight (2017) 2:e90772. doi: 10.1172/ jci.insight. 90772

227. Singh D, Ganesan AP, Panwar B, Eschweiler S, Hanley CJ, Madrigal A, et al. $\mathrm{CD} 4+$ follicular helper-like $\mathrm{T}$ cells are key players in anti-tumor immunity. bioRxiv (2020) 2020.01.08.898346.

228. Gu-Trantien C, Loi S, Garaud S, Equeter C, Libin M, de Wind A, et al. CD4 follicular helper $\mathrm{T}$ cell infiltration predicts breast cancer survival. J Clin Invest (2013) 123:2873-92. doi: 10.1172/JCI67428

229. Knochelmann HM, Smith AS, Dwyer CJ, Wyatt MM, Mehrotra S, Paulos CM. CAR T Cells in Solid Tumors: Blueprints for Building Effective Therapies. Front Immunol (2018) 9:1740. doi: 10.3389/fimmu.2018.01740

230. Lee DW, Gardner R, Porter DL, Louis CU, Ahmed N, Jensen M, et al. Current concepts in the diagnosis and management of cytokine release syndrome. Blood (2014) 124:188-95. doi: 10.1182/blood-2014-05-552729

231. Suntharalingam G, Perry MR, Ward S, Brett SJ, Castello-Cortes A, Brunner MD, et al. Cytokine Storm in a Phase 1 Trial of the Anti-CD28 Monoclonal Antibody TGN1412. New Engl J Med (2006) 355:1018-28. doi: 10.1056/ NEJMoa 063842

232. Freeman CL, Morschhauser F, Sehn L, Dixon M, Houghton R, Lamy T, et al. Cytokine release in patients with CLL treated with obinutuzumab and possible relationship with infusion-related reactions. Blood (2015) 126:2646-9. doi: 10.1182/blood-2015-09-670802

233. Winkler U, Jensen M, Manzke O, Schulz H, Diehl V, Engert A. Cytokinerelease syndrome in patients with B-cell chronic lymphocytic leukemia and high lymphocyte counts after treatment with an anti-CD20 monoclonal antibody (rituximab, IDEC-C2B8). Blood (1999) 94:2217-24. doi: 10.1182/ blood.V94.7.2217.419k02_2217_2224

234. de Vos S, Forero-Torres A, Ansell SM, Kahl B, Cheson BD, Bartlett NL, et al. A phase II study of dacetuzumab (SGN-40) in patients with relapsed diffuse large B-cell lymphoma (DLBCL) and correlative analyses of patient-specific factors. J Hematol Oncol (2014) 7:44. doi: 10.1186/1756-8722-7-44

235. Rotz SJ, Leino D, Szabo S, Mangino JL, Turpin BK, Pressey JG. Severe cytokine release syndrome in a patient receiving PD-1-directed therapy. Pediatr Blood Cancer (2017) 64:e26642. doi: 10.1002/pbc.26642

236. Tonini G, Santini D, Vincenzi B, Borzomati D, Dicuonzo G, La Cesa A, et al. Oxaliplatin may induce cytokine-release syndrome in colorectal cancer patients. J Biol Regul Homeost Agents (2002) 16:105-9.

237. Aue G, Njuguna N, Tian X, Soto S, Hughes T, Vire B, et al. Lenalidomideinduced upregulation of CD80 on tumor cells correlates with T-cell activation, the rapid onset of a cytokine release syndrome and leukemic cell clearance in chronic lymphocytic leukemia. Haematologica (2009) 94:1266-73. doi: 10.3324/haematol.2009.005835

238. Yildizhan E, Kaynar L. Cytokine release syndrome. J Oncol Sci (2018) 4:13441. doi: 10.1016/j.jons.2018.09.002

239. Murthy H, Iqbal M, Chavez JC, Kharfan-Dabaja MA. Cytokine Release Syndrome: Current Perspectives. Immunotarg Ther (2019) 8:43-52. doi: 10.2147/ITT.S202015

240. Shimabukuro-Vornhagen A, Gödel P, Subklewe M, Stemmler HJ, Schlößer HA, Schlaak M, et al. Cytokine release syndrome. J Immunother Cancer (2018) 6:56. doi: 10.1186/s40425-018-0343-9

241. Chen F, Teachey DT, Pequignot E, Frey N, Porter D, Maude SL, et al. Measuring IL-6 and sIL-6R in serum from patients treated with tocilizumab and/or siltuximab following CAR T cell therapy. J Immunol Methods (2016) 434:1-8. doi: 10.1016/j.jim.2016.03.005

242. Teachey DT, Lacey SF, Shaw PA, Melenhorst JJ, Maude SL, Frey N, et al. Identification of Predictive Biomarkers for Cytokine Release Syndrome after Chimeric Antigen Receptor T-cell Therapy for Acute Lymphoblastic Leukemia. Cancer Discovery (2016) 6:664-79. doi: 10.1158/2159-8290.CD16-0040

243. Porter DL, Levine BL, Kalos M, Bagg A, June CH. Chimeric antigen receptormodified T cells in chronic lymphoid leukemia. N Engl J Med (2011) 365:725-33. doi: 10.1056/NEJMoa1103849

244. Pathan N, Hemingway CA, Alizadeh AA, Stephens AC, Boldrick JC, Oragui $\mathrm{EE}$, et al. Role of interleukin 6 in myocardial dysfunction of meningococcal septic shock. Lancet (2004) 363:203-9. doi: 10.1016/S0140-6736(03)15326-3

245. Klinger M, Brandl C, Zugmaier G, Hijazi Y, Bargou RC, Topp MS, et al. Immunopharmacologic response of patients with B-lineage acute lymphoblastic leukemia to continuous infusion of T cell-engaging CD19/ CD3-bispecific BiTE antibody blinatumomab. Blood (2012) 119:6226-33. doi: 10.1182/blood-2012-01-400515

246. Kummar S, Takimoto C. Novel Designs of Early Phase Trials for Cancer Therapeutics. Cambridge, Massachusetts, USA: Academic Press (2018).

247. van der Stegen SJC, Hamieh M, Sadelain M. The pharmacology of secondgeneration chimeric antigen receptors. Nat Rev Drug Discovery (2015) 14:499-509. doi: 10.1038/nrd4597

248. King AC, Pharm D BCOP, Orozco JS. Axicabtagene Ciloleucel: The First FDA-Approved CAR T-Cell Therapy for Relapsed/Refractory Large B-Cell Lymphoma. J Advanced Practitioner Oncol (2019) 10(8):878-82. doi: 10.6004/jadpro.2019.10.8.9

249. Hay KA, Hanafi L-A, Li D, Gust J, Liles WC, Wurfel MM, et al. Kinetics and biomarkers of severe cytokine release syndrome after CD19 chimeric antigen receptor-modified T-cell therapy. Blood (2017) 130:2295-306. doi: 10.1182/ blood-2017-06-793141

250. Topp MS, Gökbuget N, Stein AS, Zugmaier G, O’Brien S, Bargou RC, et al. Safety and activity of blinatumomab for adult patients with relapsed or refractory B-precursor acute lymphoblastic leukaemia: a multicentre, singlearm, phase 2 study. Lancet Oncol (2015) 16:57-66. doi: 10.1016/S1470-2045 (14) $71170-2$ 
251. Le R, Li L, Yuan W, Shord SS, Nie L, Habtemariam BA, et al. FDA Approval Summary: Tocilizumab for Treatment of Chimeric Antigen Receptor T CellInduced Severe or Life-Threatening Cytokine Release Syndrome. Oncologist (2018) 23:943-7. doi: 10.1634/theoncologist.2018-0028

252. Strati P, Ahmed S, Kebriaei P, Nastoupil LJ, Claussen CM, Watson G, et al. Clinical efficacy of anakinra to mitigate CAR T-cell therapy-associated toxicity in large B-cell lymphoma. Blood Adv (2020) 4(13):3123-27. doi: 10.1182/bloodadvances.2020002328

253. Ruella M, Kenderian SS, Shestova O, Klichinsky M, Melenhorst JJ, Wasik $\mathrm{MA}$, et al. Kinase inhibitor ibrutinib to prevent cytokine-release syndrome after anti-CD19 chimeric antigen receptor $\mathrm{T}$ cells for B-cell neoplasms. Leukemia (2017) 31:246-8. doi: 10.1038/leu.2016.262

254. Kalaydina R-V, Bajwa K, Qorri B, Decarlo A, Szewczuk MR. Recent advances in "smart" delivery systems for extended drug release in cancer therapy. Int J Nanomed (2018) 13:4727-45. doi: 10.2147/IJN.S168053

255. Tran S, DeGiovanni P-J, Piel B, Rai P. Cancer nanomedicine: a review of recent success in drug delivery. Clin Transl Med (2017) 6:44. doi: 10.1186/s40169017-0175-0

256. Roybal KT, Williams JZ, Morsut L, Rupp LJ, Kolinko I, Choe JH, et al. Engineering T Cells with Customized Therapeutic Response Programs Using Synthetic Notch Receptors. Cell (2016) 167:419-32.e16. doi: 10.1016/j.cell.2016.09.011

257. Chen X, Bäumel M, Männel DN, Zack Howard OM, Oppenheim JJ. Interaction of TNF with TNF Receptor Type 2 Promotes Expansion and Function of Mouse CD4 CD25 T Regulatory Cells. J Immunol (2007) 179:154-61. doi: 10.4049/jimmunol.179.1.154

258. Schioppa T, Moore R, Thompson RG, Rosser EC, Kulbe H, Nedospasov S, et al. $\mathrm{B}$ regulatory cells and the tumor-promoting actions of TNF- $\alpha$ during squamous carcinogenesis. Proc Natl Acad Sci USA (2011) 108:10662-7. doi: 10.1073/pnas.1100994108

259. Zhao X, Rong L, Zhao X, Li X, Liu X, Deng J, et al. TNF signaling drives myeloid-derived suppressor cell accumulation. J Clin Invest (2012) 122:4094-104. doi: 10.1172/JCI64115

260. Mrowietz U, Schwenk U, Maune S, Bartels J, Küpper M, Fichtner I, et al. The chemokine RANTES is secreted by human melanoma cells and is associated with enhanced tumour formation in nude mice. Br J Cancer (1999) 79:102531. doi: 10.1038/sj.bjc.6690164
261. Wang R-X, Yu C-R, Dambuza IM, Mahdi RM, Dolinska MB, Sergeev YV, et al. Interleukin-35 induces regulatory B cells that suppress autoimmune disease. Nat Med (2014) 20:633-41. doi: 10.1038/nm.3554

262. Fernando RII, Castillo MD, Litzinger M, Hamilton DH, Palena C. IL-8 Signaling Plays a Critical Role in the Epithelial-Mesenchymal Transition of Human Carcinoma Cells. Cancer Res (2011) 71:5296-306. doi: 10.1158/ 0008-5472.CAN-11-0156

263. Koch AE, Polverini PJ, Kunkel SL, Harlow LA, DiPietro LA, Elner VM, et al Interleukin-8 as a macrophage-derived mediator of angiogenesis. Science (1992) 258:1798-801. doi: 10.1126/science.1281554

264. David J, Dominguez C, Hamilton D, Palena C. The IL-8/IL-8R Axis: A Double Agent in Tumor Immune Resistance. Vaccines (2016) 4:22. doi: $10.3390 /$ vaccines 4030022

265. Zhang H, Chua KS, Guimond M, Kapoor V, Brown MV, Fleisher TA, et al. Lymphopenia and interleukin-2 therapy alter homeostasis of CD4+CD25+ regulatory T cells. Nat Med (2005) 11:1238-43. doi: 10.1038/nm1312

266. Berger C, Berger M, Hackman RC, Gough M, Elliott C, Jensen MC, et al. Safety and immunologic effects of IL-15 administration in nonhuman primates. Blood (2009) 114:2417-26. doi: 10.1182/blood-2008-12-189266

267. Gaggianesi M, Turdo A, Chinnici A, Lipari E, Apuzzo T, Benfante A, et al. IL4 Primes the Dynamics of Breast Cancer Progression via DUSP4 Inhibition. Cancer Res (2017) 77:3268-79. doi: 10.1158/0008-5472.CAN-16-3126

268. Ellyard JII, Simson L, Parish CR. Th2-mediated anti-tumour immunity: friend or foe? Tissue Antigens (2007) 70:1-11. doi: 10.1111/j.13990039.2007.00869.x

Conflict of Interest: The authors declare that the research was conducted in the absence of any commercial or financial relationships that could be construed as a potential conflict of interest.

Copyright (C) 2020 Zhang, Guan and Jiang. This is an open-access article distributed under the terms of the Creative Commons Attribution License (CC BY). The use, distribution or reproduction in other forums is permitted, provided the original author(s) and the copyright owner(s) are credited and that the original publication in this journal is cited, in accordance with accepted academic practice. No use, distribution or reproduction is permitted which does not comply with these terms. 